\title{
Lazaroa
}

\section{Conceptual baseline for a global checklist of gypsophytes}

\author{
Juan F. Mota ${ }^{1}$, Juan Antonio Garrido-Becerra ${ }^{1}$, Francisco Javier Pérez-García ${ }^{1}$, Esteban Salmerón-Sánchez ${ }^{1}$, \\ Pedro Sánchez-Gómez ${ }^{2} \&$ Encarna Merlo ${ }^{1}$
}

Received: 13 October 2016 / Accepted: 4 November 2016

\begin{abstract}
The link between plants and gypsum soil dates back to the 19th century. In recent years, an increasing number of articles have dealt with this very special type of flora from various perspectives. The existence of crusts on the soil, xericity and nutritional imbalances that these plants - some of which are mineral accumulators - are submitted to, have turned them into interesting subjects of study at different levels, from the molecular to the biogeographical and macroecological ones. These plants might represent a relevant model for research on vegetal evolution and specialization, due to the high number of endemisms that concentrate on gypsum, some of them very local and seriously endangered in many cases. As a matter of fact, the Habitats Directive in the E.U. does not only include several gypsophile species, but it also considers gypsum outcrops priority habitats. The creation of a global gypsophytes checklist may favour the possibility to increase knowledge about this interesting flora further. Nevertheless, as there are many gypsum territories in the world, the elaboration of such a list demands the participation of an ever growing number of researchers and local experts. Four aspects have been deemed of interest in this research for the creation of a checklist:

Firstly, discussion about whether to consider "gypsum-tolerant plant" and "gypsophyte" (gypso- from the Greek, gypsum and -phyte, plant) as synonymous terms or not, as happens with "salt-tolerant plant" and "halophyte" (or "salt tolerance" and "halophily"). In the second place, there is the terminological question that affects all those words derived from the root gyps- (gypsophile, gypsicolous, gypsovag ...) which should be standardized so as to facilitate scientific communication. The third question is related to the gypsiferous soils, or maybe it would better to call them gypsic horizons as the gypsum contents of these can be critical in order to discriminate between gypsophytes and plants that are not so. The fourth aspect deals with the possibility to use chemical composition or stoichiometry in order to discriminate between gypsophytes and the rest of plants, or at least, to discriminate between the accumulative strategy and other nutritional strategies. Finally, a fifth aspect remains to be discussed, highlighting, at least superficially, which territories (in this case, countries) are those where the putative existence of gypsophile flora is believed to appear.

Having examined these questions through the revision of 91 papers resulting from a search on Scopus it is clear that gypsum-tolerance and gypsophily cannot be accepted as synonyms. In addition, gypsophytes, at least for the time being, cannot be defined in any other way but resorting to the classical or inductive criterion, i.e., plants growing exclusively on gypsum. As regards soils, the level of gypsum gypsophile vegetation can tolerate is frequently over $50 \%$. Apart from that, although the accumulator strategy is common among gypsophytes, especially of Ca and S, this is not a trait that can be generalized, as is not the fact that these minerals should concentrate on leaves. Roots, at least in the case of $\mathrm{Ca}$, can also accumulate large quantities. So far, research on gypsophily has focused on around ten countries, which is noteworthy when compared to the 75 where references or signs of gysophile flora have been found; this makes it even more interesting to elaborate a checklist that could broaden knowledge in this area.
\end{abstract}

Keywords: gypsophile; gypsophyte; gypsicolous; gypsovag; global checklist; flora; accumulator strategy.

\section{[es] Base conceptual para un catálogo global de gipsófitos verificado}

Resumen. El vínculo entre las plantas y los suelos de yeso (gipsofilia) puede remontarse hasta el siglo XIX. Durante los últimos años ha sido creciente el número de artículos que se han ocupado, desde diferentes puntos de vista, de esta flora tan peculiar. La existencia de costras en el suelo, la xericidad y los desequilibrios nutricionales que afrontan estas plantas, algunas de ellas acumuladoras de ciertos minerales, las convierte en interesantes objetos de estudio a diferentes escalas, desde la molecular a la biogeográfica y macroecológica. Estas plantas pueden representar un interesante modelo para el estudio de la evolución y especiación vegetal por el gran número de endemismos que se concentran en los yesos, algunos de ellos muy locales y en no pocos casos seriamente amenazados. De hecho, la Directiva Hábitats

Departamento de Biología y Geología, Universidad de Almería. E-04120-Almería.

Departamento de Biología Vegetal, Área de Botánica, Facultad de Biología, Universidad de Murcia, Campus Universitario de Espinardo. E- 30100-Murcia. 
de la UE no sólo incluye varias especies gipsófilas, sino que considera a los afloramientos de yeso un hábitat prioritario. La creación de un catálogo o checklist de gipsófitos a nivel global puede impulsar el conocimiento de esta interesante flora. Sin embargo, puesto que existen muchos territorios yesíferos repartidos por todas las regiones de la Tierra, la elaboración de este listado requiere la participación de un gran número de investigadores y expertos locales. Para construir esa checklist, cuatro aspectos fueron considerados de interés en esta investigación.

En primer lugar la discusión en torno a si pueden ser considerados sinónimos "planta gipso-tolerante" (capaz de crecer sobre el yeso) y gipsófito, por analogía con "planta resistente a la salinidad" y halófito (o "tolerancia a la salinidad" y "halofilia"). Esta discusión se extendería a los conceptos de gipso-tolerante y gipsofilia. En segundo lugar está la cuestión terminológica que afecta sobre todo a las palabras derivadas de la raíz gyps- (gipsofilo, gipsicola, gypsovago,...), así como a toda una serie de adjetivos complementarios (estricto, verdadero, preferente, extendido,...). En este caso la cuestión fundamental es si gipsofito y gipsofilo pueden emplearse indistintamente. La tercera cuestión está relacionada con los suelos yesíferos o quizás sea mejor decir con los horizontes gípsicos ya que el contenido en yeso de los mismos puede ser crítico a la hora de discriminar entre un gipsófito y una especie que no lo sea. El cuarto aspecto tiene que ver con la posibilidad de utilizar la composición química o estequiométrica para distinguir a los gipsófitos de las plantas que no lo son o, al menos, para separar la estrategia acumuladora de otras estrategias nutricionales. Y quedaría un quinto, poner sobre la mesa aunque sea de forma somera, aquellos territorios (en este caso países) de los que se tiene noticia que pueden tener una flora gipsófila.

Tras examinar estas cuestiones a través de la revisión de 91 artículos obtenidos de una búsqueda en Scopus, es evidente que no se pueden considera sinónimos la gipso-tolerancia y la gisofilia. Además, los gipsófitos, al menos de momento, no pueden definirse de otra manera que no sea recurriendo al criterio clásico o inductivo, i.e., plantas que crecen exclusivamente en el yeso. Por lo que respecta al suelo, el nivel de yeso que soporta la vegetación gipsófila suele estar frecuentemente muy por encima del 50\%. Por otra parte, aunque entre los gipsófitos es frecuente la estrategia acumuladora, en especial de $\mathrm{Ca}$ y $\mathrm{S}$, no es un rasgo generalizable como tampoco lo es que esos minerales se concentren exclusivamente en las hojas. Las raíces, al menos en el caso del $\mathrm{Ca}$, también pueden acumular grandes cantidades. Hasta ahora la investigación sobre la gipsofilia se ha concentrado en unos 10 países, lo que contrasta con los 75 en los que se han encontrado referencias o indicios que pueden albergar flora gipsófila, circunstancia que pone de manifiesto el interés de elaborar una checklist para favorecer el conocimiento de este tipo de flora.

Palabras clave: gipsófilo; gipsícola; gipsófito; gipsovago; lista verificada global; flora; estrategia acumuladora.

\section{Introduction}

The interest in plants species present on especial substrates has grown considerably during recent years. Halophytes and serpentinophytes are a good evidence for that. Salt tolerance refers to various morphological, physiologi$\mathrm{cal}$, and biochemical adaptations that enable plants to survive and complete their life cycles in saline environments. Such plant species are often referred to as halophytes (SaslisLagoudakis \& al., 2014). For the study of this type of plants, a database was started and compiled by James Aronson during the 1980s: his 'HALOPH, a Data Base of Salt Tolerant Plants of the World' was published in 1989 (Santos \& al., 2016). The primary criterion for inclusion in HALOPH was "known or presumed tolerance to electrical conductivity measuring (or estimated to be) at least $7.8 \mathrm{dS} \mathrm{m}^{-1}$, during significant periods of the plant's entire life" (Aronson, 1989). Since the publication of, information has been updated (Menzel \& Lieth, 2003) and nowdays it is available as a webpage which is continuously growing (Santos \& al., 2016; http://www.sussex.ac.uk/ affiliates/halophytes/index.php). According to the way this checklist is elaborated, a halophyte is a plant that completes its life cycle in a salty environment; many survive in seawater or even higher concentrations of salt.

In the case of serpentines, it is possible to find the International Serpentine Ecology Society; yet, according to the available information, it is not running the development of a data base about plants growing on this type of substrate. Despite this, a number of monographs have been so far published worldwide (Baker \& al., 1992; Roberts \& Proctor, 2013) as well as many articles about species that are able to accumulate heavy metals (Baker \& Brooks, 1989; Baker \& al., 1994; Galardi \& al., 2007; Sheoran \& al., 2011), a widespread trait in serpentinophyle plants. Boyd \& al. (2009) mention different points of biological interest for the study of serpentine outcrops, mainly: soil characterization, the knowledge of their peculiar biota, the species-area relationship and (edaphic) island biogeography, phylogenetic and evolutionary aspects related to adaptation (serpentine syndrome) and endemicity, the genetic basis of the tolerance to hostile environment (xericity and metal hyperaccumulation), ecophisiological and 
environmental aspects linked to the mineral uptake, accumulation, translocation and exclusion as well as applied aspects such as land biogeochemical exploration, phytoremedition and conservation biology.

Undoubtedly, the potential use of these plants as phytoremediators is one of the main points of interest of this kind of flora (Dushenkov \& al., 1997; Sheoran \& al., 2011; Khan \& Sajad, 2013), a feature that can also be extended to halophytes, whose high potential to accumulate different elements (Hasanuzzaman \& al., 2014) has been demonstrated. In some cases, this ability has been used even with the aim to carry out biogeochemical prospection of valuable minerals (Reid \& Hill, 2010; 2013; Reid \& al., 2008).

Moreover, halophilous flora allows its very study from different points of relevance, including economical ones (Hameed \& Khan, 2011). Perhaps the most relevant aspect which is constantly emphasized is the need to increase productivity of the wide arid and saline areas from the Earth under challenging environmental conditions so as to feed the global population (Bennet \& al., 2013; Bromham, 2014).

In the case of gypsophily research (Parsons, 1976), all the aspects cited before are present, regarding the interest and utility of these special floras. For instance, given that up to $0.7 \%$ of the terrestrial surface harbor gypsum outcrops and that most of them are present in arid regions (IUSS Working Group WRB, 2015), their genetic background can be used to improve the crop productivity in low productivity environments. In addition to this, there is no doubt about their usefulness in restoring degraded lands and facing climatic change, as these plants are regarded as the most resistant to drought (Merlo \& al., 2011). Moreover, although little exploited, these plants show a high potential as phytorremediators, since they can accumulate high levels of minerals such as Boron (Babaoglu \& al., 2004) or Strontium (Mota \& al., 2017), this last with radioactive isotopes (Dushenkov \& al., 1997; Kartosentono \& al., 2001; Singh \& al., 2004). Additionally, their presence can be useful to detect new mineral resources, such as gypsum (Escavy \& al., 2012). Recently, it has been demonstrated that these plants are able to extract crystalline or structural water (Palacio \& al., 2014), a property that could be used in hostile environments where there is no other way to access this resource, as would happen in the still distant case of Mars. Following an analogy with other physical processes to extract water from gypsum (Van Der Gaag, 2008), one could speak of "water phytomining". All these reasons and others that will be presented below, can be drawn to encourage the creation of a database of plants present on gypsum outcrops.

This idea was recently presented at the first GYPNET meeting, a network of researchers working on gypsum ecosystems, that has recently taken place in Aranjuez (Madrid, Spain), and was conducted by Sara Palacio (Instituto Pirenaico de Ecología, Jaca) and Adrian Escudero (Rey Juan Carlos University, Madrid). However, before undertaking this titanic task, it would be important to clarify some basic points related to "gypsum tolerant plants", an expression relating to "salt tolerant plants", which was included in eHALOPH. Previously, Golubic (1980) pointed at the difference between "halotolerance" and "halophily", as the distinction between halophilic $\left(\mathrm{Na}^{+}\right.$-requiring) and halotolerant organisms is not suitable to describe the entire spectrum of adaptations to salt. Silva-Graca \& al. (2003) go further when they affirm that in the case of yeast while halotolerance is a clear, well established concept, halophily may be a concept of very limited nature and thus, of doubtful use. For a better understanding of the question, it could be rephrased as follows: Are a "halophyte" and "salt tolerant plant" the same? If this were true, a "gypsophyte" would be the same as a "gysum tolerant plant" and "gypso-tolerance" could be denominated as "gypsophily". This question is much more important and transcendent than it seems to be, as the term "gypsophyte" has been used to refer to plants growing exclusively on gypsum soils or gypsisols (cf. Merlo \& al., 1998, 2009; Escudero \& al., 1999; Cerrillo \& al., 2002; Mota \& al., 2003). Therefore, a first point to solve arises before the development of a database on gypsum plants. Is it necessary to look for species capable of completing their live cycle on gypsum soils, or plants that grow exclusively on this kind of soils? For example, and according to the first criterion, there would be hundreds of gypsum tolerant species in Spain, but only a few more than 30 "growing exclusively on gypsum soils". Therefore, such widely distributed species in Spain as Macrochloa tenacissima or Helianthemum 
syriacum are clearly gypsum tolerant plants, to the extent that they can be some of the most abundant species in terms of coverage in the Iberian gypsum (Mota \& al., 2010). However, none of them can be considered exclusive of gypsum outcrops (Mota \& al., 2009; 2011). Also, there could be further discussion on the ecological behavior of species such as Lygeum spartum or different species of Limonium genus. All of them could be grouped under the definition of "halophytic gypsophiles" (Parsons, 1976), "gypsohalophytic species" (Denaeyer-De Smet, 1970) or "halothiophores" (Duvigneaud \& Denaeyer-De Smet, 1968). The existence of a close contact between gypsum and saline areas (e.g. Esteve \& Varo, 1975; Escudero \& al., 2000) blurs at times the frontier between salt tolerant plants and those exclusive of gypsum (Sánchez del Pino \& al., 1999; Maldonado \& al., 2001). The fact that sodium rich soils contain significant amounts of sulfate and gypsum (Waisel, 1972) does not help either.

The terminology used regarding gypsum plants is a second key aspect. This terminology can not only make the results of the research more diffuse, but can also hinder communication among researchers. For instance, both Escudero \& al. (1999) and Eugenio \& al. (2012) use the terms "gypsophytes" and "gypsophiles" in the same publication and with similar meaning. The same can be found in Waterfall (1946) with "gypsophilous" and "gypsophile", although in this case they were used as adjectives. A high number of authors use the latter term to describe "species confined to gypsum soils" (e.g. Parsons, 1976; Northington, 1976; Meyer, 1986; Moore \& Jansen, 2007; Hadjikyriakou \& Hand, 2011; Palacio \& al., 2012). In other words, "gypsophile" can be regarded as a synonym of "gypsophyte". As a result of the use of "gypsophile" as a noun (actually, it is an substantivated adjective), many anglo-saxon authors, among which "gypsophile" is widely used, have been forced to look for "another" adjective in order to refer to the fact of living on gypsum environments; "gypsophilous", above mentioned, and "gypsophilic" fall in this category. In addition, it is be possible to add a lot of adjectives to express the degree of "gypsophily" of a plant (gypsicolous, gypsocline, gypsovags, gypsophobe ...). Additionally, it is very common to associate terms such as "gypsophytes" and "gyp- sophiles" to adjectives like "specialist", "obligate", "genuine", "true", "full", ... (e.g. Pueyo \& al., 2007; Palacio \& al., 2007; Meyer \& al., 1992; Escudero \& al., 1997; Drohan \& Merkler, 2009; Douglas \& Manos, 2007). All this has led to the increase in terminological confusion (Mota \& al., 2011), and has hindered scientific communication. Still, the most worrying thing might be that this terminological tangle has also helped to hide the existing and persisting difficulties in the definition of what gypsophily is, or in more precise words, which the real reason is behind the restriction of some plants to gypsiferous soils or the underlying mechanism involved in gypsum tolerance.

Another important question has to do with determining the existence of the exact correspondence between "gypsum soils", an expression that most of the authors who have studied gypsophily use, and the so called "gypsisols" (Spaargaren, 2008). For instance, Bogdanovic \& al. (2008) and Martínez-Duro \& al. (2010) refer specifically to gypsisols as the substrate of gypsophytes. This is not a minor issue, as formal definition of gypsisols "soils with a significant accumulation of pedogenetic gypsum $\left(\mathrm{CaSO}_{4} \cdot 2 \mathrm{H}_{2} \mathrm{O}\right)$ in the solum" (Driessen \& al., 2001), is ambiguous. What is exactly "a significant accumulation"? To answer this, it would be necessary to refer to the terms considered by the IUSS Working Group WRB (2015). This Group mentions three types of gypsic horizonts: gypsic, with a gypsum content above 5\%; hypogypsics, with gypsum content lower than $25 \%$, and hypergysic, if this content is higher than $50 \%$. However, Van Alphen \& Rios Moreno (1971) refer to the term "gypsiferous soils" to those containing more than 2\% gypsum. Curiously, for many gypsophily researchers (Bridges \& Burnham, 1980; Escudero \& al., 1999), the limit of $25 \%$ in gypsum has become a reference value. This percentage began to settle since Van Alphen \& Rios Romero (1971) concluded that up to $25 \%$ of gypsum has little or no effect on crops unless it is cemented. According to these authors, wherever the gypsum content is over $25 \%$ there are problems of ion imbalance and impaired water holding capacity, whilst cementation by gypsum is an obstacle to the penetration of roots and water. Moreover, Verheye \& Boyadgiev (1997) consider that the percentage in gypsum in which physical surface crusts are present is over 
$25 \%$. More recently, the IUSS Working Group (2014) has stated that even soils containing $25 \%$ powdery gypsum or more could still produce excellent yields of alfalfa and others crops, if irrigated at high rates in combination with forced drainage. Five, 25 and 50 percentages could be very interesting reference values in the study of gypsophily, but it is important to bear in mind that they refer to cultivated soils and that, as in FAO classification (and other related), they belong to the field of agriculture. Sadly, there are very few studies that have tried to establish the link between plants and gypsum soil percentage, but some of them might be of use when discussing these percentages more in depth (Merlo \& al., 2009; Salmerón \& al., 2014). In any case, there is an increased difficulty that has been presented when talking about the halogypsophilous character of some species, which is related to typically saline soils such as the solonetz and the solonchaks in which gypsic horizon may also occur. This horizon, although less frequently, is also found in gleysols, vertisols, andosols, chernozems, kastanozems, phaeozems, durisols, calcisols, lixisols, luvisols and leptosols (IUSS Working Group WRB, 2015).

Classic works about Spanish and Northafrican gypsum plants mention the ability of many of them to accumulate $\mathrm{Ca}, \mathrm{S}$ and Mg (Boukhris \& Lossaint, 1970, 1973, 1975). This is also one of the most redundant aspects in the most recent papers. In a historical survey on the study of the relations between plants and gypsum, it is possible to recognize two types of factors which have been considered determinant to explain gypsophily. On the one hand, the chemical or nutritional factors, and on the other hand the physical ones; the latter are linked to the crusting that gypsum can suffer and the xeric water regime of these soils (Merlo \& al., 1998; Moore \& al., 2014; Escudero \& al., 2015). This dichotomy when characterizing gypsophily phenomenon is already present in the seminal work of Parsons (1976). However, and perhaps due to the great influence of Meyer's (1986) paper, the mineralogical or stereochemical composition of gypsophile plants was pushed into the background and physical factors became dominat in research (e.g. Romão \& Escudero, 2005; Pueyo \& al., 2007). Despite this, some of the more recent papers about this subject have encouraged research on gypsophytes' capability to accumulate specific mineral ele- ments (Palacio \& al., 2007; Drohan \& Merkler, 2009; Salmerón \& al., 2014). Two recent reviews about gypsophily have taken this point into account (Moore \& al., 2014; Escudero \& al., 2015), dubbed by Merlo \& al., (1998) as "chemical hypothesis". Although the accumulative ability of certain gypsophile species is probably not the only nutritional strategy that these plants can follow to cope with gypsic mineral imbalanced soils, it is evident that it represents a trait of great interest from the physiological, ecological and evolutionary points of view, as well as practical due to the different posibilities that it could offer in phytoremediation. However, only few authors have insisted on the need to establish more or less accurate limits and objectives according to which plants could be considered as accumulators. Unlike the research dealing with heavy metal accumulating plants (Baker \& Brooks, 1989). In fact, only a few researchers after Parsons (1976) have remembered the "old" limits pointed by Boukhris \& Lossaint (1970, 1973, 1975) and Duvigneud \& Denaeyer de-Smet $(1966,1968,1973)$ in their publications, perhaps with the exception of Drohan \& Merkler (2009). Establishing a reference threshold between "common" plants and gypsophytes (accumulators) can be useful for the progress in the research of gypsophily.

The main objective of this research is to establish a conceptual baseline for a global checklist of gypsophytes. To achieve this objective it is fundamental to:

1.- Clarify the existing relationships between the concepts "gypsum-tolerance" and "gypsophily" and, therefore, between "gypsum tolerant plants" and "gypsophytes" (or "gypsophiles"). This regards establishing the definition of what a gypsum tolerant plant is and linking this idea with the fact that, in addition, it grows exclusively (or almost) on this kind of substrate.

2.- Standardize nomenclature associated with gypsophily and to which degree this can be found; moreover bearing in mind the existence of many plants able to survive on gypsum (gypsum tolerant), without being exclusive of this kind of substrate.

3.- Establish which the gypsum percentage in soils should be, that could determine the growth and survival capability of plants that 
are not specifically adapted, starting from the information available and taking into account that gypsophily is a phenomenon linked to gypsum substrates.

4.- Characterize the phenomenon of gypsophily, according to the available information, through the adaptative syndromes that this geobotanical phenomenon produces on plants, especially as regards mineral composition, in order to identify gypsophile plants or gypsophytes according to the most objective criteria.

5.- Contribute information about the existence of gypsophyly and, thus, of gypsophytes in different countries around the world according to the recent revision of Pérez-García \& al. (2016) and other data sources with the final aim of favouring the creation of a global database and international involvement. The structure of this database will be based on eHALOPH (Santos \& al., 2016).

To achieve these objectives, in the case of the first four, a revision of over 90 papers contained in SCOPUS database (accessed on 24/02/16) has been carried out, that are more or less deeply concerned with gypsophily. Moreover, and regarding the diferential ability of gypsophytes to accumulate some minerals ( $\mathrm{Ca}, \mathrm{S}$ and $\mathrm{Mg}$ ) in organs other than leaves, unpublished data until now about mineral composition of the root of some plant species are shown. All togehter, concepts and ideas discussed here are useful in order to construct a database of gypsophile flora, which could serve all researchers interested in more than local works, and for planning phylogenetic, evolutionary, ecophisiological and macroecological studies

\section{Material and Methods}

Ninety one papers dealing with gypsophily and gypsophile flora, included in SCOPUS, a citation database of peer-reviewed scientific literature, have been reviewed. Key words used in this bibliographical search, which took place in 24/02/16 were: "gypsocline", "gypsophile", "gypsophilic", "gypsophilous", "gypsophily", "gypsophobe", "gypsophyte", "gypsovag" and "gypsum-tolerant". These papers are marked with * among the references (and in the Appendix). In addition to these, some classic papers have also been taken into account (e.g. Johnston, 1941; Parsons, 1976). Within each of these references definitions of "gypsophily" and the rest of related terms, as well as those that could be considered synonyms or deriving from them have been searched. In the latter case, compound terms associated with those used as a basis for the search were common (e.g. "true gypsophile", "near gypsophile", "wide gypsophile" ...). From that point, the present study has tried to establish if there are any accurate definitions of basic terms such as "gypsophily", "gypsophyte" or "gypsophile" to keep on enlarging the knowledge of gypsum plants. Accuracy of these terms and their degree of acceptance and use among expert researchers in gypsum plants are two key questions for the progress in this research field.

On the other hand, and given that edaphic characteristics are an essential element with respect to the gypsophily phenomenon, definitions that IUSS Working Group WRB (2015) offers about gypsiferous soils or gypsisols as well as about the gypsic horizons were taken into account.

In addition to the nature of the soil, chemical plants composition was also recurrently present in some definitions of the terms used to refer to gypsum plants. All available information about the mineral composition of these plants has been considered here (e.g. Palacio \& al., 2007; Moore \& al., 2014). Special attention was paid to those papers where both aspects, soil and plant (mineral composition and abundance) were jointly referred to (cf. Merlo \& al., 2009; Salmerón-Sánchez \& al., 2014). In the case of the chemical composition of plants, all references found (with the exception of Tuyukima, 2009 and Mota \& al., 2017) mentioned leaves. However, it has been found that roots can even develop a main role in order to explain the existing link between soilplant in gypsum outcrops (Rincón \& al., 2008; Alguacil \& al., 2009a, 2009b, 2012; Özdemir \& al. 2010; Palacio \& al., 2012; Torrecillas \& al., 2014) and even stems (Weinert \& Sakri, 1977). For this reason, complementary data have been added to this research regarding mineral contents of the roots from 15 species belonging to Almeria's classic locations for gypsophile flora: Sierra de Almagro, Venta de los Yesos and Karst en Yesos de Sorbas (Mota \& al., 2011), during winter of the year 2010 . Determinations were performed following the methods from Servicio de Ionómica of 
CEBAS (Centro de Edafologia y Biologia Aplicada del Segura; CSIC, Murcia, Spain), from a solid, dried and grinded sample. Total Carbon and total Nitrogen analysis was performed through an Elemental Analyzer. Furthermore, 29 cations were measured by means of ICP-OES (Inductively coupled plasma atomic emission spectroscopy), where plasma acts as ionization source, along with an optic emission spectrophotometer (OES). This methodology presents excellent detection limits and lineal dynamic range, multi-element capability, low chemical interference and a stable and reproducible signal.

\section{Results and Discussion}

\section{Gypsum tolerance vs gypsophily}

Parsons (1976), in which could be considered the foundational paper for the modern study of gypsophily, defines this phenomenon as "The widespread occurrence of plant species confined to gypsum soils (gypsophiles) [...]". Following Mota \& al. (2011), Parsons adopted an inductive approach according to which the gypsophile character of a species would be reinforced the more the number of cases were documented in which the presence of this species on gypsum outcrops increases, and never (or only accidentally) if this happened out of this kind of substrate. This is directly related to the fidelity shown by plants to gypsum without pointing to an explicative cause of this behaviour. In this case, documented observations of experts are valuable information sources such as bibliographic references that forthrightly indicate the presence of plants on gypsum (floristic or sintaxonomical) and herbaria vouchers that explicitly mention the linkage between plant and gypsum (MartínezHernández \& al., 2009, 2011, 2015). Likewise, the presence of any species on gypsum would not be enough to indicate whether it is a gypsophyte (or gypsophile), especially if it is also frequent in other types of substrate i.e., if it is not confined to gypsum. According to Douglas \& Manos (2007), these species would be gypsum-tolerant. In fact, gypsovags or gypsumtolerant species are often more abundant within vegetation associated to gypsum than strict gypsophytes (Mota \& al., 2010). In gypsiferous territories where complete floristic catalogues are available, the percentage of known plants that grow exclusively on gypsum is minimal
(Emerson, 1935; Waterfall, 1946; Barber, 1979, Buckallew, 2015; Caddell \& al., 2013; Akpulat \& al., 2005; Rick, 2012; Dehshiri \& Jozipoor, 2014; Martínez-Hernández, 2013). However, in all these cases it is also clear that there are some species which occur only on gypsum and are endemic to these territories.

It is evident that the inductive criterion does not provide any explanation about gypsophily phenomenon. Although it would be ideal to understand all the causes for this confinement to gypsum, these have not yet been fully established (Palacio \& al., 2007). By defining a species as gypsophytes (or gypsophiles), hypotheses are put forward to seek explanations for the phenomenon of gypsophily, or according to Popper, hypotheses to falsify it (Popper, 1959). One of this hypothesis confronts two ideas, refuge vs specialist plants, which has not been suggested exclusively for gypsophile flora (Mota \& al., 2017). The latter suggests that plants growing on special substrates (serpentine, gypsum, dolomite, ...) present ecophysiological and morpho-anatomical adaptations to support the limitations of this type of soils (xericity, nutritional unbalance, ...), i.e. these plants would be specialists. If this were so, gypsophytes could be easily recognized as such. This idea can be taken further if it is considered that plants inevitably need this kind of substrate (or the resources that it contains) to thrive. In the case of gypsum, for instance, it could be large quantities of $\mathrm{Ca}$. Strictly speaking, this would be the "true gypsophily" but so far, no one has openly proposed such an idea.

Escudero \& al. (2015) have criticized the development of a gypsophytes checklist from expert criteria based on the knowledge of botanists familiar with the flora of gypsum outcrops (Mota \& al., 2009, 2011). According to their approaches, there is an obvious link between the extent of the distribution of some plants and their specific strategies for living in gypsum, due to their capacity to perforate the soil crust (Romão \& Escudero, 2007) and their ability as accumulators of $\mathrm{Ca}$ and $\mathrm{S}$ (Palacio \& al., 2007); recent researches call in question this so direct and suggestive relationship (Moore \& al., 2014; Bolukbasi \& al., 2016). Following this idea, "wide gypsophiles" would be specialist in overtaking edaphic crusts and $\mathrm{Ca}$ and $\mathrm{S}$ accumulator, while "narrow gypsophiles" would show a less specific profile and would be refugee species (Escudero \& al., 2015). Thus, narrow gyp- 
sophiles exhibit a very similar strategy to that of the gypsovags or gypsum-tolerant species without the ability to accumulate $\mathrm{Ca}, \mathrm{S}$ and other minerals. However, only in the Iberian Peninsula it is possible to find, at least, five distribution patterns in gypsophytes (PérezGarcía \& al., 2011). The wider distributed species would be those from the circunmediterranean area (or even greater, reaching C. Asia), as is the case of Campanula fastigia$t a$. With a more restricted area, but exceeding Iberian territories, iberomaghrebian elements are found such as Lepidium subulatum, Helianthemum squamatum or Ononis tridentata s.l. All these species are qualified as "wide gypsophiles" (Palacio \& al., 2007; Escudero \& al., 2015), as is the case of Gypsophila struthium s.l. or Herniaria fruticosa despite the fact that these latter species are Iberian endemisms. Species like Santolina viscosa, Thymus lacaitae, Centaurea hyssopifolia or Chaenorrhinum grandiflorum s.l. are regional endemisms, whereas Teucrium turredanun, T. lepicephalum o Heliathemum alypoides could be considered as local endemisms. Considering all the mentioned species and other gypsophytes, very different strategies for living on gypsum (Merlo \& al., 1998; Moore \& al., 2014) can be found and it is possible to find plants that could be considered as accumulators (in roots and leaves) like Helianthemum syriacum among gypsovag species. Since not all species respond to the same nutritional, macroecological or biogeographical patterns, it will be necessary to expand the study of this type of plants to a global scale before generating a consistent theory as occurs with halophily. To date, according to the cases reviewed, the inductive approach is nearly always backing the plants indicated as gypsophytes (or gypsophiles; Table 1). Although in the study of halophily the concepts "salt tolerant plant" and "halophyte" overlap greatly (Szota \& al., 2015), this does not happen in gypsophily, when speaking of "gypsum tolerant plants" and "gypsophytes".

\section{Gypsophytes, gypsophiles and related terms}

In the definition of gypsophily by Parsons (1976), the term "gypsophile" is also clearly defined. This was the most widely used term (56\% of the reviewed articles) to deal with gypsum plants (Table 1) even over "gypso- phyte" $(54 \%)$. Other terms also related to the study object in this type of researches such as "gypsophilous" or "gypsophily" are only present in one third of the works (37 and $31 \%$ ). Indeed, "gypsophile" corresponds to an adjective, although its use is common as a noun (Mota \& al., 2011). In this latter case, it is a nominalized adjective whose use is legitimate and frequent, following the tradition initiated by Parsons (1976), although Waterfall (1946) did use this term previously (along with gypsophilous and gypsophytes) as well. However, in a strict sense, "gypsophile" was used for the first time by Reyes Prósper (1915) and some years later by Huguet del Villar (1925), although both implemented it in their native language, Spanish.

According to the "gypsophytes" and "gypsophiles" wide use as nouns, it would probably be advisable to maintain them to refer to gypsum plants. Nevertheless, the "gypsophile" concept is broader due to the fact that it could make reference to any living being, for instance to an animal, a fungus, or a prokaryote. This happens for example with "halophile" (Golubic, 1980; Edbeib \& al., 2016). In this sense, if what is wanted is to designate a vascular plant, it would be preferable to use "gypsophyte" (gypso- from the ancient Greek, gypsum and -phyte, plant) or "gypsophile plant (s)". The use of "gypsophile" (gypso-, gypsum and -phile, lover) solely would be restricted as an adjective and would remain synonymous with "gypsophilous" and "gypsophilic", terms far less used. In any case, in order to perform a web indexing of papers and bibliographic databases, it may be advisable that researchers ensure the presence of the terms "gypsophytes" and "gypsophiles", at least in the main title, keywords or abstract of the publication.

It is frequent to find that in those papers in which "gypsophile" is used as a noun, other adjectives are used as well to express the "gypsum-lover" quality (e.g. Lowrey \& al., 1994; Ferriol \& al., 2006; Moore \& al., 2007; Nesom \& al., 2007; Martínez-Duro \& al., 2012; Aguirre-Liguori \& al., 2014; Dehshiri \& Jozipoor, 2014; Porras-Alfaro \& al., 2014). Among them, "gypsophilous" is the most used (37\%), followed distantly by "gypsophilic" (12\%) and "gypsicolous" (2\%). In fact, out of 22 times that "gypsophyte" and "gypsophile" are used in the same paper, only in tree (Hadjikyriakou \& Hand, 2011; Queiroz \& al., 
Table 1. Concepts in the reviewed papers on gypsophily

\begin{tabular}{|l|c|c|}
\hline \multicolumn{1}{|c|}{ Concepts } & Number of papers & \% \\
\hline DEFINITION (gypsophily or gypsophile) & 42 & 46,15 \\
\hline GYPSOPHILY & 28 & 30,77 \\
\hline GYPSOPHYTE & 49 & 53,85 \\
\hline GYPSOPHILE & 51 & 56,04 \\
\hline GYPSOPHILOUS & 34 & 37,36 \\
\hline GYPSOPHILIC & 11 & 12,09 \\
\hline NON-GYP & 19 & 20,88 \\
\hline HALO-GYP / SALT / SALINE & 4 & 4,40 \\
\hline GYPSOVAG & 23 & 25,27 \\
\hline GYPSUM-TOLERANT & 3 & 3,30 \\
\hline GYPSOCLINE & 6 & 6,59 \\
\hline SUBGYPSOPHYTE & 3 & 3,30 \\
\hline GYPSICOLOUS & 2 & 2,20 \\
\hline GYPSOPHOBES & 2 & 2,20 \\
\hline NEAR-GYPSOPHILES & 1 & 1,10 \\
\hline WAIF / ACCIDENTAL & 3 & 3,30 \\
\hline STRICT & 17 & 18,68 \\
\hline SPECIALIST / MODEL & 19 & 20,88 \\
\hline OBLIGATE & 11 & 12,09 \\
\hline GENUINE & 8 & 8,79 \\
\hline TRUE & 5 & 5,49 \\
\hline FULL & 1 & 1,10 \\
\hline DOMINANT & 4 & 4,40 \\
\hline FACULTATIVE & 4 & 4,40 \\
\hline PREFERENT / PREFERENTIAL & 5 & 5,49 \\
\hline REFUGIA / REFUGEES / MODEL & 5 & 5,49 \\
\hline WIDE & 3 & 3,30 \\
\hline NARROW / LOCAL / ENDEMICS & 9 & 9,89 \\
\hline GENERALIST & 2 & 1,10 \\
\hline INSULAR & 6,59 \\
\hline EDAPHISM & 3 & 2,20 \\
\hline
\end{tabular}

2012; Dehshiri \& Jozipoor, 2014) there is no Spanish coauthor present. In two of the papers (Escudero \& al., 1999; Matesanz \& al., 2009), "gypsophyte" and "gypsophile" are used indistinctly as nouns. In two additional ones, despite the fact that in the text the term "gypsophiles" is used exclusively, it is also possible to find "gypsophytes" among the keywords (Palacio \& al., 2007; Bolukbasi \& al., 2016). Only Queiroz \& al. (2012) consider that "gypsophytes" is a general concept that can be subdivided in two categories: "gypsophiles" and "gypsovags".

Merely this last term puts on the table what could be denominated "degree of gypsophily" (Mota \& al., 2009, 2011), an idea already advanced in the work of Huguet del Villar (1925), who introduced terms such as "subgypsophile" and "gipsoades" (gypsum-tolerant). With regard to this issue, the term "gypsovags" can be found among the most used in literature $(25 \%)$. In fact, using different terms with the root "gypso-" it would be possible to establish the degree of gypsophily. Starting with the highest gypsum preference, there would be those species considered as "gypsophiles" (Table 1), followed by "gypsoclines" (term used in 7\% of the revised papers; e.g. Meyer, 1986; Meyer \& al., 1992; Mota \& al., 2009; Drohan \& Merkler, 2009; Escudero \& al., 2015; Robins \& al., 2014), followed by "gypsicolous" (Mota \& al., 2004, 2010), "gypsovags" (Meyer, 1986; Escudero \& al., 1997; Cerrillo \& al., 2002; Ferriol \& al., 2006; Palacio \& al., 2007; Romão \& Escudero, 2005), and finally "gypsophobes" (2\%, Meyer, 1986; Escudero \& al., 2014). The same scale could be used considering other terms such as: "true", "obligate", "strict", "genuine" or "full" gypsophiles (e.g. Oyonarte \& al., 
2002; Drohan \& Merkler, 2009), "preferential", "near" or "sub-gypsophiles" (Meyer, 1986; Cerrillo \& al., 2002), "facultative" or "generalist" gypsophiles (Oyonarte \& al., 2002; Moore \& Jansen, 2007), "waif" or "accidental" gypsophiles (Meyer, 1986; Mota \& al., 2009) and "non-gypsophiles" (Northington, 1976; Mota \& al., 2003; Table 1). The term "gypsophile" can also be found along with other adjectives, although not to indicate the degree of gypsophily in a plant species, but other characteristics like its distribution"narrow", "local", "endemic", "wide" or "insular" (e.g. Pueyo \& al., 2008; Castillejo \& al., 2011; Soriano \& al., 2014; Cañadas \& al., 2014) or abundance (Eugenio \& al., 2012; Soriano \& al., 2014; Cañadas \& al., 2014); still, as has been described above, some of this characteristics are associated to the ecological behavior of these plants (e.g. Palacio \& al., 2007; Escudero \& al., 2015).

\section{Gypsisols and gypsum soil content}

Taking into consideration the 91 references included in this review, almost $50 \%$ of them hold a more or less accurate definition of the gypsophily phenomenon. Within these definitions, it is possible to establish two large typologies. On the one hand, those that refer to the substrate (gypsum) or, more specifically, to the type of soil (32 papers) where this gypsum-lover plants grow (gypsisols); and on the other hand, those mentioning some ecological or physiological characteristics (13 papers) that these plants present. In the case of soils, IUSS Working Group WRB (2015) considers three key levels regarding gypsum content to interpret gypsophily: $5 \%, 25 \%$ and $50 \%$. Among them, $25 \%$ has been the most recurrent value used (Escudero \& al., 1999, 2014; Romão \& Escudero, 2005). This threshold is based on the work developed by Van Alphen \& Rios Romero (1971), who concluded that up to $25 \%$ of gypsum has little or no effect on crops unless it is cemented. According to these authors, wherever gypsum content is over $25 \%$ there are problems of ion imbalance and impaired water holding capacity, whilst cementation by gypsum is an obstacle to the penetration of roots and water. However, IUSS Working Group WRB (2015) indicates that even soils containing $25 \%$ powdery gypsum or more could still produce excellent crop yields if irrigated at high rates in combination with forced drainage. Apart from agriculture and cultivated plants, there is very little information that links natural vegetation to the percentages in gypsum of the soil directly.

Table 2 has been elaborated based on these data reported by Merlo \& al. (2009) and Salmerón \& al. (2014). In it, it is possible to see some summarized data of coverage and richness of species considered as gypsophile in relation to the percentage of gypsum in soil. Gypsum content of these soils varies between less than $3 \%$ and over $90 \%$. The percentage of gypsum in soils where two species considered as gypsophile are dominant is higher than $75 \%$, whereas the minimum value is above $50 \%$ and the limit of quartile 1 is about $65 \%$. These values decrease to 54,8 and $22 \%$ (approximately), when the most abundant species is a gypsophyte and the codominant one is a gypsovag. Whenever coverage of the set of gypsophytes is over $50 \%$, the average percentage of gypsum reaches about $87 \%$. In this case, the minimum value is around $72 \%$ and the first quartile exceeds $80 \%$. Perhaps, the most significant of these values is the percentage for gypsum found in those soils in which coverage of gypsophytes presents values below $50 \%$. In these cases, the average value is near $41 \%$, the minimal value is under $3 \%$ and $18 \%$ for the first quartile. The existing relation between gypsophytes' richness (number of species) and percentage of gypsum also shows very interesting results. Among the 12 samples considered here, richness in gypsophytes was never higher than 50\% (Table 3 ). The maximum value was $40 \%$ and the average was around $27 \%$. Vegetation samples with a percentage of gypsophile species higher than $25 \%$ showed soils with an average $62 \%$ in gypsum content, a minimal value of $22 \%$ of and of $45 \%$ for the first quartile. In samples where the percentage of gypsophytes (richness) was below $25 \%$ (6 samples), values were 48.2 and $7 \%$ respectively. Among all present gypsophytes in at least one third of the samples (4 relevés), Helianthemum squamatum (7 samples) was the species with higher average levels of gypsum in soils (79\%) and Hernaria fruticosa (9 samples) for the lower ones, but near to $50 \%$ (Table 3 ). No other gypsophyte showed values lower than $50 \%$. The average value for these six gypsophytes considered was of almost $63 \%$. Among gypsovags present in at least 4 of the samples, values were much higher than $50 \%$ in average gypsum content and species such as Macrochloa tenacissima (6 samples) or Lithodora fruticosa (4 samples) were present on soils with an average gypsum content above $65 \%$. 
Table 2. Gypsum percentage in soils (from Merlo \& al., 2009 and Salmerón \& al., 2014). 2 GPHY = samples with 2 dominants gypsophytes; GPHY-GVAG = samples with a gypsophyte and a gypsovag as codominants species; C_GPHY = gypsophtes covert; R_GPHY = gypsophytes richness. In brackets the number of samples (n)

\begin{tabular}{|l|c|c|c|c|c|c|c|}
\hline & $\begin{array}{c}\text { TOTAL } \\
(12)\end{array}$ & $\begin{array}{c}2 \text { GPHY } \\
(5)\end{array}$ & $\begin{array}{c}\text { GPHY- } \\
\text { GVAG (3) }\end{array}$ & $\begin{array}{c}\text { C_GPHY } \\
\mathrm{S}>50(4)\end{array}$ & $\begin{array}{c}\text { C_GPHY } \\
\mathrm{S}<50(8)\end{array}$ & $\begin{array}{c}\text { R_GPHY } \\
\mathrm{S}>25(7)\end{array}$ & $\begin{array}{c}\text { R_GPHY } \\
\mathrm{S}<25(5)\end{array}$ \\
\hline MEAN & 56,24 & 77,18 & 54,35 & 86,90 & 40,91 & 62,01 & 48,16 \\
\hline Q1 & 33,43 & 66,78 & 21,47 & 83,40 & 18,08 & 45,27 & 7,91 \\
\hline Q2 & 63,02 & 79,25 & 72,10 & 89,19 & 45,27 & 54,71 & 71,33 \\
\hline Q3 & 81,08 & 89,65 & 79,05 & 92,69 & 58,87 & 85,14 & 72,10 \\
\hline MAX & 97,10 & 97,10 & 91,22 & 97,10 & 79,05 & 97,10 & 87,16 \\
\hline MIN & 2,32 & 53,12 & 7,91 & 72,10 & 2,32 & 21,47 & 2,32 \\
\hline
\end{tabular}

Table 3. Mean gypsum \% in soils for some gypsophile and gypsovag species (data from Merlo \& al., 2009 and Salmerón \& al., 2014). Abbreviations are: G: tentative gypsophily degree; CG: Gypsovag;

NG: narrow-gypsophile; WG: wide gypsophile

\begin{tabular}{|l|c|c|c|c|}
\hline SPECIES & $\mathrm{G}$ & $\mathrm{n}$ & $\%$ GYPSUM & sd \\
\hline Helianthemum squamatum & WG & 7 & 79,02 & 14,38 \\
\hline Macrochloa tenacissima & GV & 6 & 67,10 & 74,81 \\
\hline Lithodora fruticosa & GV & 5 & 65,36 & 20,27 \\
\hline Gypsophila struthium subsp. struthium & WG & 9 & 64,73 & 31,15 \\
\hline Thymus vulgaris & GV & 4 & 63,01 & 41,36 \\
\hline Launaea fragilis & GV & 6 & 63,00 & 26,11 \\
\hline Helianthemum syriacum & GV & 5 & 62,89 & 22,73 \\
\hline Koeleria valesiana subsp. castellana & NG & 5 & 62,16 & 33,81 \\
\hline Lepidium subulatum & WG & 6 & 56,45 & 25,94 \\
\hline Ononis tridentata & WG & 8 & 51,03 & 35,64 \\
\hline Jurinea pinnata & GV & 10 & 50,62 & 32,40 \\
\hline Sedum sediforme & GV & 4 & 48,25 & 43,90 \\
\hline Herniaria fruticosa & WG & 9 & 47,41 & 32,63 \\
\hline
\end{tabular}

Regarding gypsiferous soils, it is clear that the "gypsisol" concept is not useful in gypsophily research without more information about gypsum content percentage and other physicalchemical parameters (as the presence of $\mathrm{NaCl}$ ). At least, that is obvious from the above data which relate gypsophile vegetation and soils. It is evident that values found in the literature on the effects of the percentage in gypsum are related to crops and, therefore, subjected to artificial conditions. Without denying the great value of this information, gypsophily research should also focus on wild plants because it is in them that the phenomenon is defined. From this point of view, it would be very important to know abundance and proportion of gypsophile plants present on this kind of substrate.
Curiously, while H. squamatum is the most frequent species among all those in the 116 phytosociological tables studied by Mota \& al., (2010), among the first ten samples there are no strictly gypsophile (gypsovag) species such as Helianthemum syriacum, Launaea fragilis, Teucrium capitatum, Rosmarinus officinalis, Atractylis humilis or Sedum sediforme. The above mentioned $M$. tenacissima and L. fruticosa may be found among the first fifteen. However, it is important to bear in mind that all these species which are not strictly gypsophile display a distribution that in many cases comprises most of the Iberian Peninsula and that, among gypsophytes, only species such as Ononis tridentata, Helianthemum squamatum, Herniaria fruticosa, Lepidium 
subulatum or Gypsophila struthium s.l. show a comparable geographic amplitude. These "wide gypsophiles", in the sense given by Palacio \& al. (2007) and Escudero \& al., (2015), are among the ten most frequent taxa on gypsum. These five species are also the taxa with a larger total coverage in the Spanish gypsum outcrops according to the review of Mota \& al. (2010), although $R$. officinalis is placed in the fourth place ahead of $H$. fruticosa. Among the ten most abundant gypsovags species in Iberian gypsum, the above mentioned $H$. syriacum and Brachypodium retusum are also present. In $83.63 \%$ of the studied tables by Mota \& al., (2010) a strict gypsophyte was dominant or codominant, a value that is near to that obtained when the 12 samples considered here are analyzed (11/12).

Very rarely are gypsophytes predominant in gypsum vegetation regarding species richness (number of species), although they are where coverage is concerned. These can be more interesting situations for the study of gypsophily, as the selective effect of gypsum is doubtless in them. With respect to percentages of gypsum collected from literature, it is clear that the 5\% threshold lacks interest as is rarely near to the percentage of gypsum that supports predominantly gypsophilous vegetation, at least in Iberian Peninsula case. The $25 \%$ does not seem to be a very selective value either, as in this case gypsovags species are usually predominant. It is striking that the minimum percentage of gypsum to get a majority of gypsophytes coverage must be of at least $75 \%$. According to the information provided, a gypsophyte should be able to live in soils with very common gypsum percentages above $50 \%$, i.e., hypergypsics horizons. Furthermore, Poch \& al. (1998) found that roots are seldom found in horizons with gypsum content higher than $60 \%$. It is risky to precise this value further as the analysis was performed with a reduced number of cases and all of them restricted to Spanish gypsum outcrops, although those 12 soils considered here are spread throughout all the Iberian geography in which gypsum is present.

\section{Gypsophytes as Ca, $\mathrm{S}$ and $\mathrm{Mg}$ accumulators, towards a deductive rule?}

As has been commented above, almost half of the reviewed papers offer a definition (or at least they try to) of gypsophily or of what a gypsophile species is. In 13 papers, authors refer to gypsophytes as plants capable of accumulating calcium or sulfur (even magnesium), but in none of them is the limit mentioned from which a species can be considered an accumulator. An exception is Drohan \& Merkler's paper (2009), despite the fact that they commit a mistake when considering the values shown by Parsons (1976) to establish the limit according to which a plant is regarded as gypsophile. However, these levels are clearly established in the case of heavy metals hyperaccumulators, especially in the case of leaves (Baker \& Brooks, 1989; Baker \& al., 1994).

Not even Escudero \& al. (2015) in their recent review of gypsophily, refer to these limits. Neither Palacio \& al. (2007), nor Moore \& al. (2014) or Bolukbasi \& al. (2016), despite their studying foliar stoichiometry of some gypsophytes. What it is possible to find in some of these cited references are comparisons with the contents in other plants or partial mentions to the data originating from classical works of [values provided by] Duvigneaud \& Denaeyer de-Smet, 1968; Boukhris \& Loisant, 1970, 1972 and 1975). However, in these classics papers, the limits that can be considered as "normal" are neither reflected. This separation threshold can be very important. High concentrations of heavy metals, especially $\mathrm{Ni}$ are frequent among plants that grow on serpentine (Megoni \& al., 2010). According to Baker \& Brooks (1989) the criterion for hyperaccumulation varies for different metals and represents a concentration in above-ground dry matter greatly in excess of "normal" or physiological levels. This accumulation is present not only in leaves, but also in roots (Galardi \& al., 2007).

The revised papers that deal with gypsum plants rarely refer to determinate levels of $\mathrm{Ca}$, $\mathrm{S}$ or $\mathrm{Mg}$, a fact from which it could be possible to confirm that a species is an "accumulator". This criterion can be essential in order to interpret gypsophily. To solve this question, in addition to the critical review of classical texts (e.g. Duvigneud \& Denaeyer-de Smet, 1968; Boukhris \& Loissant, 1970, 1972), alternative approaches can be of great interest. One of them consists in exploring publications about plant nutrition that offer general data about which values are considered "standard" regarding these elements in plants (e.g. Lizon \& al., 1979). Those reviews which collect abundant data on foliar contents after the analysis of which generalizable average values 
(Watanabe \& al., 2007 and Houba \& Uittenbogaard, 1994) can be obtained, may also be of great interest. Thus values above 3 $3-3.5 \%(\mathrm{Ca}), 1(\mathrm{~S})$ and $0.75-1 \%(\mathrm{Mg})$, approximately are almost three times higher than those offered by Duvigneud \& Denaeyer deSmet $(1966,1968,1973)$ and Boukhris \& Lossaint, 1970; 1973, 1975), which could serve as a reference to consider a plant $\mathrm{Ca}, \mathrm{S}$ or $\mathrm{Mg}$ accumulators, respectively. These values are, in all the cases above, averages that could be obtained from Watanabe \& al. (2007) and Houba \& Uittenbogaard (1994)

Although those limits could be discussed in every case, trying to establish them may be helpful considering, as it seems to be, that they could work as a discriminating criterion (e.g. Drohan \& Merkler, 2009). The above mentioned thresholds would fit quite well with those recorded for "thiophores" species, among which most of gypsophytes (Boukhris \& Loissant, 1975) would be included. Some may argue against this idea that those limits would be lower than those indicated for "macrothiophores" (Boukhris \& Loissant, 1972) or for eu-gypsophytes (Duvigneaud \& Denaeyer de-Smet, 1973), but it is important to remember that in these categories only encompassed tree species remain, following the cited authors. Therefore, Erodium glaucophyllum would be a macrothiophore, whereas Gypsophila hispanica and Ononis tridentata would be eu-gypsophytes. However, these values are well suited to those ranges that Boukhris \& Loissant (1972) established for "mesothiophore" species, among which "classic" gypsophytes can be found such as Lepidium subulatum, Helianthemum squamatum or Herniaria fruticosa.

According to data compiled by Moore \& al. (2014) only "wide gypsophiles", in Palacio's \& al. (2007) sense, would present values higher than the above mentioned, although it would be necessary to exclude two species with a large presence on gypsum from this category such as Frankenia thymifolia and Sedum gypsicola. In fact, Frankenia thymifolia shows the highest $\mathrm{Ca}$ content known in leaves to date, for the Spanish gypsophile flora (but see Mota \& al., 2017). Also, Helianthemum syriacum, a gypsovag, could be in the threshold of the considered values. According to these criteria the so-called "narrow gypsophiles" would be excluded from the accumulator gypsophytes list, at least which would be so if only foliar contents published until now, are taken into account (Palacio \& al., 2007; Moore \& al., 2014). However, that is not the case when considering roots. As can be seen in Table 4 many of them exceed, in the case of $\mathrm{Ca}, 3 \%$ dry weight.

It has already been pointed out that there may be accumulations of $\mathrm{Ca}$ and other minerals in other plant organs different from leaves, such as the stems and roots (Yang \& al., 1999). In the case of Gypsophila genus, druse crystals have already been detected in roots (Özdemir \& al., 2010) as well as high $\mathrm{Ca}$ and S levels (Mota \& al., 2017). Table 4 shows that this is not an exception. This accumulation does not only occur in wide gypsophiles, such as Ononis tridentata or Gypsophila struthium, but is also present in a large number of narrow gypsophiles, like Teucrium torredanum and T. balthazaris. This pattern is also recognizable in some gypsovags such as Helianthemum syriacum and Anthyllis cytisoides (Table 4). It seems logical to consider that within the gypsophily phenomenon, any plant organ may be considered as an accumulator of any of these three elements, although it should be noted that neither $\mathrm{S}$ nor $\mathrm{Mg}$ appear to be in roots at the same levels as they appear in the leaves. Mota \& al. (2017) also add another mineral element to consider when studying gypsophily; that is $\mathrm{Sr}$, in which gypsiferous soils are so rich (Rosell \& al., 1998; Kasprzyk, 2013). In fact, according to the established limits for some heavy metals (Baker \& Brooks, 1989), some gypsophytes could be considered even as Sr hyperaccumulators. In Teucrium turredanun (unpublished data) and, especially, Gypsophila struthium (Mota \& al., 2017), high percentages of this element have already been found in roots.

Although $\mathrm{Ca}, \mathrm{S}$ and $\mathrm{Mg}$ levels in plant tissue might be of great help to identify gypsophytes, a word of caution is needed about their use as discriminants. To begin with, there is an effect that could be called "taxonomical", represented in the case of $\mathrm{S}$ in crucifers and other related families (e.g. Resedaceae). Richness in this element in secondary metabolites makes it so that almost all the members of the family show high levels of this element. In addition to this, a physiological effect might be highlighted in the case of $\mathrm{Ca}$, a nutrient playing many different roles in plants as a whole. Some of these functions, as those performed as osmoregulator (Knight, 2000; Ahanger \& al., 
Table 4. Root mineral composition of the studied species. Abbreviations are: Loc: Locality; AL: Almagro; SO: Sorbas; VY: Venta de los Yesos; G: tentative gypsophily degree; CG: gypsovag; NG: narrow-gypsophile; WG: wide gypsophile.

\begin{tabular}{|c|c|c|c|c|c|c|c|c|c|c|}
\hline Species & Loc & $\mathbf{G}$ & $\mathrm{C}(\%)$ & N (\%) & $\begin{array}{l}\mathrm{Ca} \\
(\%)\end{array}$ & $\mathbf{K}(\%)$ & $\begin{array}{l}\mathrm{Mg} \\
(\%)\end{array}$ & $\begin{array}{l}\mathrm{Na} \\
(\%)\end{array}$ & $\mathbf{P}(\%)$ & S (\%) \\
\hline Anthyllis cytisoides & $\mathrm{AL}$ & GV & 45,74 & 0,77 & 2,48 & 0,25 & 0,15 & 0,01 & 0,04 & 0,09 \\
\hline Anthyllis cytisoides & $\mathrm{SO}$ & GV & 48,73 & 0,92 & 4,01 & 0,31 & 0,23 & 0,02 & 0,02 & 0,18 \\
\hline Coris hispanica & SO & NG & 49,74 & 0,76 & 2,84 & 0,42 & 0,16 & 0,19 & 0,03 & 0,95 \\
\hline Coris hispanica & VY & NG & 48,11 & 0,54 & 1,10 & 0,59 & 0,09 & 0,10 & 0,02 & 0,53 \\
\hline Frankenia thymifolia & VY & WG & 46,57 & 1,37 & 1,79 & 0,18 & 0,13 & 0,08 & 0,02 & 0,72 \\
\hline Gypsophila struthium & $\mathrm{SO}$ & WG & 35,82 & 0,71 & 7,63 & 0,60 & 0,06 & 0,03 & 0,02 & 0,50 \\
\hline Gypsophila struthium & VY & WG & 40,37 & 0,61 & 7,45 & 0,63 & 0,04 & 0,04 & 0,01 & 0,32 \\
\hline $\begin{array}{l}\text { Helianthemum } \\
\text { alypoides }\end{array}$ & SO & NG & 52,20 & 0,48 & 1,43 & 0,12 & 0,07 & 0,02 & 0,02 & 0,37 \\
\hline Helichrysum stoechas & $\mathrm{SO}$ & GV & 50,91 & 1,02 & 0,48 & 1,02 & 0,02 & 0,08 & 0,07 & 0,32 \\
\hline $\begin{array}{l}\text { Helianthemum } \\
\text { squamatum }\end{array}$ & $\mathrm{AL}$ & WG & 46,37 & 0,51 & 2,68 & 0,18 & 0,21 & 0,02 & 0,02 & 0,51 \\
\hline $\begin{array}{l}\text { Helianthemum } \\
\text { squamatum }\end{array}$ & SO & WG & 46,61 & 0,62 & 1,84 & 0,19 & 0,23 & 0,29 & 0,02 & 0,57 \\
\hline $\begin{array}{l}\text { Helianthemum } \\
\text { squamatum }\end{array}$ & VY & WG & 45,39 & 0,71 & 2,99 & 0,30 & 0,13 & 0,03 & 0,04 & 0,63 \\
\hline $\begin{array}{l}\text { Helianthemum } \\
\text { syriacum }\end{array}$ & $\mathrm{AL}$ & GV & 48,80 & 0,61 & 3,77 & 0,21 & 0,14 & 0,03 & 0,02 & 0,21 \\
\hline $\begin{array}{l}\text { Helianthemum } \\
\text { syriacum }\end{array}$ & SO & GV & 47,91 & 0,44 & 4,00 & 0,17 & 0,06 & 0,02 & 0,02 & 0,37 \\
\hline $\begin{array}{l}\text { Helianthemum } \\
\text { syriacum }\end{array}$ & VY & GV & 43,97 & 0,64 & 5,56 & 0,25 & 0,10 & 0,03 & 0,03 & 0,35 \\
\hline Lepidium subulatum & VY & WG & 48,35 & 0,92 & 0,45 & 0,30 & 0,05 & 0,01 & 0,04 & 0,52 \\
\hline Ononis tridentata & $\mathrm{AL}$ & WG & 46,14 & 0,73 & 4,17 & 0,13 & 0,27 & 0,02 & 0,01 & 0,38 \\
\hline Ononis tridentata & $\mathrm{SO}$ & WG & 45,50 & 0,72 & 5,70 & 0,11 & 0,11 & 0,02 & 0,01 & 0,43 \\
\hline Rosmarinus officinalis & $\mathrm{AL}$ & GV & 52,93 & 0,53 & 0,66 & 0,34 & 0,08 & 0,09 & 0,01 & 0,23 \\
\hline Rosmarinus officinalis & $\mathrm{SO}$ & GV & 50,20 & 0,47 & 0,32 & 0,17 & 0,02 & 0,03 & 0,01 & 0,09 \\
\hline Schoenus nigricans & $\mathrm{AL}$ & GV & 44,54 & 0,31 & 2,70 & 0,11 & 0,05 & 0,06 & 0,00 & 1,41 \\
\hline Santolina viscosa & $\mathrm{AL}$ & NG & 50,36 & 0,87 & 2,37 & 0,40 & 0,28 & 0,06 & 0,03 & 0,26 \\
\hline Santolina viscosa & SO & NG & 51,73 & 0,75 & 2,10 & 0,36 & 0,04 & 0,06 & 0,03 & 0,49 \\
\hline Santolina viscosa & VY & NG & 50,58 & 0,82 & 2,65 & 0,30 & 0,06 & 0,21 & 0,02 & 1,16 \\
\hline Teucrium balthazaris & $\mathrm{AL}$ & NG & 47,77 & 1,63 & 3,94 & 0,66 & 0,24 & 0,02 & 0,02 & 0,54 \\
\hline Teucrium turredanum & $\mathrm{SO}$ & NG & 47,86 & 1,70 & 4,14 & 0,60 & 0,07 & 0,24 & 0,03 & 0,55 \\
\hline Teucrium turredanum & $\mathrm{SO}$ & NG & 47,60 & 1,66 & 4,08 & 0,57 & 0,06 & 0,23 & 0,03 & 0,54 \\
\hline
\end{tabular}

2014) make this very abundant in vacuoles (Gallaher, 1975; Beebo \& al., 2009) of species belonging to Sedum (Crassulaceae) genus (Ardelean \& al., 2011). Additionally, calcium oxalate has proven to be useful in the defence against herbivory (Molano-Flores, 2001; Nakata, 2003) and that reason might explain the high Ca levels in gypsovags legume family such as Anthyllis terniflora and $A$. cytisoides when they are growing on gypsum (unpublished data). Mota \& al. (2017) suggest that this accumulation of $\mathrm{Ca}$ could also be behind the low rates of herbivory found by Megias \& al. (2011) both for Ononis tridenta, a legume, and Gysophila struthium, two gypsophytes forming druses (Grigore \& al. 2011; Palacio \& al. 2014a). Also among the halophytes, accumulation of $\mathrm{Ca}, \mathrm{S}$ and $\mathrm{Mg}$ (Merlo \& al., 2001) is common, although in these cases the gypsophytes separation is easy because they do not accumulate large amounts of $\mathrm{Na}$. However, it is clear that there is an 
intermediate strategy long known (Duvigneaud P \& Denaeyer-de Smet, 1968, 1973; Boukhris, \& Lossaint, (1972, 1975) which allows for the use of terms such as halophytic gypsophiles, halogypsophiles or halothiophores (Parsons, 1976). Despite these cautions, data about accumulation of the four elements indicated before may be of interest to understand the gypsophily phenomenon.

Table 5. Proposed fields for the gypsum plants database

\begin{tabular}{|l|l|}
\hline & Database fields \\
\hline 1 & Family \\
\hline 2 & Genus \\
\hline 3 & Species \\
\hline 4 & Author \\
\hline 5 & Image \\
\hline 6 & Plant type \\
\hline 7 & Life form \\
\hline 8 & Ecotypes \\
\hline 9 & Soil maximum gypsum content \\
\hline 10 & Germination / Plant nursery \\
\hline 11 & Excretory glands \\
\hline 12 & Photosynthetic pathway \\
\hline 13 & Molecular data \\
\hline & Microbial interactions and mycorrhizal \\
status \\
\hline 15 & Bioremediation / Restoration ecology \\
\hline 16 & Antioxidants \\
\hline 17 & Secondary metabolites \\
\hline 18 & Stoichiometry \\
\hline 19 & Habitat \\
\hline 20 & Fitosociology /accompanying species \\
\hline 21 & Bioclimatology \\
\hline 22 & Economic use \\
\hline 23 & Distribution \\
\hline 24 & References \\
\hline 25 & Comments \\
\hline & \\
\hline
\end{tabular}

\section{Proposal for the structure of the database}

Notwithstanding the fact that some of the reasons for the global implementation of a checklist of gypsophytes have already been introduced, one last aspect remains to be discussed. The 90 articles reviewed here are restricted to only 10 countries around the world. This figure is very low when compared to the 71 that Pérez-García \& al. (2016) mentioned, which indicated the presence of gypsophile plants. Specifically, these researchers state the certain existence of this type of flora in 50 countries. This database includes, so far, 678 species and it will certainly be expanded in the future. These figures are above those found in the article by Parsons (1976), who barely cites a dozen countries with gypsophile flora. Still it is clear that much work remains to be done and many aspects to be discussed. For example, some species have been considered gypsophytes in some countries while not in others. Lygeum spartum (Boukhris \& Loissant, 1970) or Diplotaxis harra s.l. (Benabadji \& al., 2009) are clear examples of this. The involvement of local experts in the global gypsophile plants checklist will be crucial in advancing knowledge of this interesting type of edaphism. The creation of a database, on which the authors of the present study are working, and which was inspired by eHALOPH, can be helpful in starting this task. Awaiting suggestions, the structure of this database is reflected in Table 5.

\section{Conclusions}

The most widespread criterion to define what a gypsophile plant or a gypsophyte is was inductive and based on direct observation of such plants on gypsum soils, although never (or hardly ever) out of them. Actually, it is difficult to establish another criterion as there are no data available or any indisputable evidence to discriminate between this type of plants and those which accompany them in the gypsum soils; the latter can be considered as gypsum tolerant or gypsovags. In short, gypsum tolerance and gypsophily cannot be made synonyms. To continue advancing knowledge about gypsophila flora, it is necessary to rely on the definition offered by Parsons (1976), which seems not to have lost force as it is commonly applied when new gypsophile taxa (e.g. Akhani, 2004; Yildirim \& Crespo, 2014; Alexander \& al., 2014; Güemes \& al., 2016; Dehshiri \& Goodarzi, 2016; Salazar \& al., 2016) are described. In short, gypsum tolerance and gypsophily cannot be considered synonymous.

Terminology around plants with a preference for gypsum has multiplied over time since Reyes Prósper (1915) first used the word "yipsófila". It was probably Johnston (1941) who first used the term "gypsophily", which was accompanied by gypsophile, used as a noun, and "gypsophilous" as an adjective. The tradition in the use of "gypsophile" has lasted until today, but when referring to a plant, it is 
probably more accurate to use the term "gypsophyte" since gypsophile is also widely used as an adjective. Other terms with the same root (lexeme) as the above can be helpful in establishing the degree of a species' gypsophily, an idea already advanced by Huguet del Villar (1925), and can serve to clarify the ecological behaviour of these species. In fact, the degree of gypsophily of a species may vary from one territory to another, and it is an aspect of interest to better understand this geobotanical phenomenon.

According to the edaphic data available for gypsophile vegetation, the concept of gypsisol, without referring to the percentage of gypsum in the soil, seems clearly insufficient to discuss the gypsophile character of plants. It is evident that gypsophile vegetation, or rather, that with a good representation of gypsophile plants in terms of coverage and species richness, occurs in soils with a high percentages of gypsum, as happens with conductivity values to establish halophily. As soon as information on the abundance of gypsum in the soil becomes available, it may be possible to establish a minimum level of this mineral as a discriminating criterion for gypsophily. In any case, the data provided here already advance future difficulties in the study of gypsophily and the relationship between this phenomenon and gypsiferous soils. It will also be necessary to delve deeper into this latter subject following the guidelines outlined by researchers with extensive experience in this soil type (Herrero \& al., 2009; Poch \& al., 1998).

As happens with gypsum percentage in soils, the contents of $\mathrm{Ca}, \mathrm{S}$ and $\mathrm{Mg}$ in gypsophile plants can be helpful criteria to deepen the knowledge of gypsophily. Although the use of percentages of these elements in different plant organs may be suggested as a deductive criterion for gypsophily, at the moment there are not many plants analyzed outside Spain (Palacio \& al., 2007; Moore \& al., 2014), Tunisia (Boukhris \& Loisant, 1970, 1972 and 1975), USA (Drohan \& Merkler, 2009), Turkey (Bolukbasi \& al., 2016), Russia (Tuyukina, 2009) and Italy (Mendoza \& al., 2016).
However, it is clear that not all gypsophile species have this accumulator strategy and even some gypsovags are able to accumulate large amounts of any of these elements in both leaves and roots. The latter deserve much more attention than has been given them so far. Sr may be another element of interest in gypsophily research (Mota \& al., 2017). Anyhow, even if the accumulator is not the ultimate trait to establish gypsophily, it is a very important fact that should be investigated in all gypsophile species. Likewise, trying to establish boundaries that separate more or less clearly what can be understood as normal mineral percentages and those typical of the gypsophytes can help in the investigation. Some values are proposed here as thresholds to be discussed: over 3 3-3.5\% for $\mathrm{Ca}$, above $1 \%$ for $\mathrm{S}$ and higher than $0.75-1 \%$ for $\mathrm{Mg}$. For Sr. levels above $500 \mathrm{ppm}$ can already be clear deviants, even lower. However, in this case, more than in any other, it is necessary to expand the known information before setting a limit.

Until research on gypsophily progresses in the search for its causes, it will be difficult to use genetic, physiological or ecological (edaphic) criteria (Mota \& al., 2011) to establish with guarantees what a "true" gypsophyte is. Considering that the investigation of this geobotanical phenomenon has concentrated much in some countries and in a very limited group of species, it would be necessary to extend the study of this type of flora to other countries and territories, as well as to different climatic conditions. Creating a database available to all researchers may be a decisive step towards understanding gypsophily.

\section{Acknowledgements}

This research was supported by the Plan Andaluz de Investigación, Desarrollo e Innovación (Junta de Andalucía) and by ECORESGYP proyect, funded by Explotaciones Rio de Aguas S.L. E.S.S has been awarded with a postdoctoral grants (Contrato Puente, Plan Propio 2016), sponsored by the University of Almeria, Spain.

\section{References}

*Aguirre-Liguori, J.A., Scheinvar, E. \& Eguiarte, L.E. 2014. Gypsum soil restriction drives genetic differentiation in Fouquieria shrevei (Fouquieriaceae). Am. J. Bot. 101 (4): 730-736.

Ahanger, M.A., Tyagi, S. R., Wani, M.R., \& Ahmad, P. 2014. Drought tolerance: role of organic osmolytes, growth regulators, and mineral nutrients. In: Wani, M. R \& Ahmad, P (Eds.). 
Physiological mechanisms and adaptation strategies in plants under changing environment. Pp. 2555. Springer, New York.

*Akhani, H. 2004. A new spiny, cushion-like Euphorbia (Euphorbiaceae) from south-west Iran with special reference to the phytogeographic importance of local endemic species. Bot. J. Linn. Soc. 146(1): 107-121.

Akpulat, H.A. \& Celik, N. 2005. Flora of gypsum areas in Sivas in the eastern part of Cappadocia in Central Anatolia, Turkey. J. Arid Environ. 61(1): 27-46.

*Alexander, P.J., Douglas, N.A., Ochoterena, H., Flores-Olvera, H. \& Moore, M.J. 2014. Recent findings on the gypsum flora of the rim of the Guadalupe Mountains, New Mexico, U.S.A.: A new species of Nerisyrenia (Brassicaceae), a new state record, and an updated checklist. J. Bot. Res. Inst. Tex. 8 (2): 383-393.

*Alguacil, M.M., Roldan, A. \& Torres, M.P. 2009a. Complexity of semiarid gypsophilous shrub communities mediates the AMF biodiversity at the plant species Level. Microb. Ecol. 57(4): 718-727.

*Alguacil, M.M., Roldán, A. \& Torres, M.P. 2009b. Assessing the diversity of AM fungi in arid gypsophilous plant communities. Environ. Microbiol. 11(10): 2649-2659.

*Alguacil, M.M., Torrecillas, E., Roldán, A., Díaz, G. \& Torres, M.P. 2012. Perennial plant species from semiarid gypsum soils support higher AMF diversity in roots than the annual Bromus rubens (2012). Soil Biol. Biochem. 49: 132-138.

Ali, H., Khan, E. \& Sajad, M.A. 2013. Phytoremediation of heavy metals-concepts and applications. Chemosphere 91(7): 869-881.

Ardelean, M., Cachiţă-Cosma, D. \& Crăciun, C. 2011. Vacuole formations identified in the cells of the foliar mesophyll of the young leaves of Sedum telephium ssp. maximum harvested from natural environment. Studia Univ. Vasile Goldis, Ser. Stii.Viet.: 21(3): 563-571.

Aronson, J. 1989. Salt-Tolerant Plants of the World. University of Arizona. Tucson.

Babaoglu, M., Gezgin, S., Topal, A., Sade, B. \& Dural, H. 2004. Gypsophila sphaerocephala Fenzl ex Tchihat: A boron hyperaccumulator plant species that may phytoremediate soils with toxic B levels. Turk J. Agric For. 28: 273-278.

Baker, A.J.M., McGrath, S.P., Sidoli, C.M.D. \& Reeves, R.D. 1994. The possibility of in situ heavy metal decontamination of polluted soils using crops of metal-accumulating plants. Resour. Conserv. Recy. 11(1-4): 41-49.

Baker, A.J.M., Proctor, J. \& Reeves, R.D. (Eds.). 1992. Vegetation of ultramafic (serpentine) soils: Proceedings of the first International Conference on Serpentine Ecology. Univ. California, Davis.

Baker, A.J.M. \& Brooks, R.R. 1989. Terrestrial higher plants which hyperaccumulate metallic elements a review of their distribution, ecology and phytochemistry. Biorecovery 1: 81-126.

Barber, S.C. 1979. Floristic components of the gypsum hills and redbed plains area of southwestern Oklahoma. Southwest. Nat. 24(3): 431-437.

Beebo, A., Thomas, D., Der C., Sanchez, L., Leborgne-Castel, N., Marty, F., Schoefs, B. \& Bouhidel, K. 2009. Life with and without AtTIP1;1, an Arabidopsis aquaporin preferentially localized in the a opposing tonoplasts of adjacent vacuoles. Plant Mol. Biol. 70: 193-209.

Benabadji, N., Aboura, R. \& Benchouk, F.Z. 2009. La régression des steppes méditerranéennes: le cas d'un faciès à Lygeum spartum L. d'Oranie (Algérie). Ecol. Mediterr. 35: 75-91.

Bennett, T.H., Flowers T.J. \& Bromham, L. 2013. Repeated evolution of salt-tolerance in grasses. Biol. Lett. 9: 20130029. http://dx.doi.org/10.1098/rsbl.2013.0029

Bogdanović, M., Sabovljević, M., Sabovljević, A. \& Grubišić, D. 2009. The influence of gypsiferous substrata on bryophyte growth: are there obligatory gypsophilous bryophytes? Bot. Serb. 33(1): 75-82.

*Bolukbasi, A., Kurt, L. \& Palacio, S. 2016. Unravelling the mechanisms for plant survival on gypsum soils: An analysis of the chemical composition of gypsum plants from Turkey. Plant Biol. 18 (2): 271279.

Boukhris, M. \& Lossaint, P. 1970. Sur la teneur en soufre de quelques plantes gypsophiles de Tunisie. Oecol. Plant. 5:345-354.

Boukhris, M. \& Lossaint, P. 1972. Spécificité biogeochimique des plantes gypsophiles de Tunisie. Oecol. Plant. 7:45-68.

Boukhris, M. \& Lossaint, P. 1975. Aspects écologiques de la nutrition minérale des plantes gypsicoles de Tunisie. Rev. Ecol. Biol. Sol. 12: 329-248.

Bridges, E.M. \& Burnham, C.P. 1980. Soils of the state of Bahrain. J. Soil Sci. 31(4): 689-707.

Bromham, L. 2014. Macroevolutionary patterns of salt tolerance in angiosperms. Ann. Bot. (Oxford): 1-9. http://aob.oxfordjournals.org/content/115/3/333

Buckallew, R.R. 2015. Vascular Flora of the University of Central Oklahoma Selman Living Laboratory, Woodward, County, Oklahoma. Proc. Okla. Acad. Sci. 83: 31-45.

Caddell, G.M. \& Rice, K.D. 2013. Vascular Flora of Alabaster Caverns State Park, Cimarron Gypsum Hills, Woodward County, Oklahoma. Okla. Nat. Plant Rec. 12(1):43-62. 
*Cañadas, E.M., Ballesteros, M., Valle, F. \& Lorite, J. 2014. Does gypsum influence seed germination? Turk. J. Bot. 38: 141-147.

*Castillejo, J.M., Castelló, R., Cristobal, A.G.S. \& Abad, S. 2011. Soil-plant relationship along a semiarid gypsum gradient (Rio de Aguas, SE Spain). Plant Ecol. 212(8): 1287-1297.

*Cerrillo, M.I., Dana, E.D., Castro, H., Rodríguez-Tamayo, M.L. \& Mota, J.F. 2002. Selección de áreas prioritarias para la conservación de flora gipsícola en el sureste de la Península Ibérica. Rev. Chil. Hist. Nat. 75(2): 395-408.

*Dehshiri, M.M. \& Goodarzi, M. 2016. Taxonomic Notes on Hedysarum sect. Crinifera (Fabaceae) in Iran, with the Description of a New Species. Annal. Bot. Fenn. 53(1-2): 21-26.

*Dehshiri, M.M., \& Jozipoor, M. 2014. Angiosperms, Kuhdasht gypsum areas, Lorestan, Iran. Check List 10(3): 516-523.

Denaeyer-De Smet, S. 1970. Note on the chemical composition of salts secreted by various gypsohalophytic species of Spain. Bull. Soc. Roc. Bot. Belg. 103: 273-278.

*Douglas, N.A. \& Manos, P.S. 2007. Molecular phylogeny of Nyctaginaceae: Taxonomy, biogeography, and characters associated with a radiation of xerophytic genera in North America. Am. J. Bot. 94(5): 856-872.

Driessen, P., Deckers, J., Spaargaren, O. \& Nachtergaele, F. 2001. Lecture notes on the major soils of the world (No. 94). FAO, Rome.

*Drohan, P.J. \& Merkler, D.J. 2009. How do we find a true gypsophile?. Geoderma 150(1): 96-105.

Dushenkov, S., Kapulnik, Y., Blaylock, M., Sorochisky, B., Raskin, I. \& Ensley, B. 1997. Phytoremediation: a novel approach to an old problem. Stud. Environ. Sci. 66: 563-572.

Duvigneaud, P \& Denaeyer-De Smet, S. 1966. Accumulation du soufre dans quelques espèces gypsophiles d’Espagne. Bull. Soc. Roc. Bot. Belg. 99: 263-269.

Duvigneaud, P. \& Denaeyer-De Smet, S. 1968. Essai de classification chimique (elements mineraux) des plantes gypsicoles. Bull. Soc. Roy. Bot. Belg. 101: 279-291.

Duvigneaud, P. \& Denaeyer-De Smet, S. 1973. Considerations sur l'ecologie de la nutrition minerale des tapis vegetaux naturels. Oecol. Plant. 8: 219-246.

Edbeib, M.F., Wahab, R.A., \& Huyop, F. 2016. Halophiles: biology, adaptation, and their role in decontamination of hypersaline environments. World J. Microbiol. Biotechnol. 32(8): 1-23.

Emerson, F.W. 1935. An ecological reconnaissance in the White Sands, New Mexico. Ecology 16(2): 226-233.

Escavy, J.I., Herrero, M.J. \& Arribas, M.E. 2012. Gypsum resources of Spain: Temporal and spatial distribution. Ore Geol. Rev. 49: 72-84.

*Escudero, A., Albert, M.J., Pita, J.M. \& Pérez-García, F. 2000. Inhibitory effects of Artemisia herba-alba on the germination of the gypsophyte Helianthemum squamatum. Plant Ecol. 148(1): 71-80.

*Escudero, A., Carnes, L.F. \& Pérez-García, F. 1997. Seed germination of gypsophytes and gypsovags in semi-arid central Spain. J. Arid Environ. 36(3):487-497.

*Escudero, A., Iriondo, J.M., Olano, J.M., Rubio, A. \& Somolinos, R.C. 2000. Factors affecting establishment of a gypsophyte: The case of Lepidium subulatum (Brassicaceae). Am. J. Bot. 87(6): 861-871.

*Escudero, A., Palacio, S. Maestre, F.T. \& Luzuriaga. A.L. 2015. Plant life on gypsum: A review of its multiple facets. Biol. Rev. Camb. Philos. Soc. 90: 1-18. DOI: 10.1111/brv.12092

*Escudero, A., Somolinos, R.C., Olano, J. \& Rubio, A. 1999. Factors controlling the establishment of Helianthemum squamatum, an endemic gypsophile of semi-arid Spain. J. Ecol. 87(2): 290-302.

Esteve, F. \& Varo, J. 1975. Estudio geobotánico de las comunidades halófilas interiores de la provincia de Granada. Anales Inst. Bot. Cavanilles 32(2): 1351-1374.

*Eugenio, M., Molina, C. \& Montamarta, G. 2013. The conservation of high-interest plant species offers the chance to preserve unique and vulnerable representatives of gypsum steppes. In: Morales Prieto, M.B. \& Traba Díaz, J. (Eds.). Steppe Ecosystems: Biological Diversity, Management and Restoration, Pp. 197-209. Nova Sciencie Pub. Inc., Madrid.

*Ferriol, M., Pérez, I., Merle, H. \& Boira, H. 2006. Ecological germination requirements of the aggregate species Teucrium pumilum (Labiatae) endemic to Spain. Plant Soil 284(1-2): 205-216.

Galardi, F., Corrales, I., Mengoni, A., Pucci, S., Barletti, L., Barzanti, R., M. Arnetoli, Gabbrielli,R. \& Gonnelli, C. 2007. Intra-specific differences in nickel tolerance and accumulation in the Ni-hyperaccumulator Alyssum bertolonii. Environ. Exp. Bot. 60(3): 377-384.

Gallaher, R.N. 1975. The occurrence of calcium in plant tissue as crystals of calcium oxalate 1. Commun. Soil Sci. Plant Anal. 6(3): 315-330.

Golubic, S. 1980. Halophily and halotolerance in cyanophytes. In: Ponnameperuma, C. \& Margulis, L. (Eds.). Limits of Life. Pp. 69-83. Reidel Publishing Company, Dordrecht, Boston and London.

Grigore, M.N., Toma, C., Zamfirache, M.M. \& Boscaiu, M. 2011. Anatomical considerations on Spanish gypsophytes. Where is their place within plant ecology? Scientific Annals of Alexandru Ioan Cuza University of Iasi New Series, Section 2 Plant Biology 57: 31-38. 
*Güemes, J., Marchal, F., Carrió, E. \& Blasco, M.P. 2016. A new gypsophilous species of Chaenorhinum (Antirrhinaceae) from the south-east of the Iberian Peninsula. Plant Biosyst. 150 (1): 141-151.

*Hadjikyriakou, G. \& Hand, R. 2011. Teucrium salaminium Hadjik. \& Hand (Lamiaceae, Teucrium sect. Polium), a new species from Cyprus. Candollea, 66(2): 341-345.

Hameed, A. \& Khan, M.A. 2011. Halophytes: biology and economic potentials. Karachi University J. Sci. 39(1): 40-44.

Hasanuzzaman, M., Nahar, K., Alam, Md. M., Bhowmik, P.C., Hossain, Md.A., Rahman, M.M., Prasad, M.N.V., Ozturk, M. \& Fujita, M. 2014. Potential use of halophytes to remediate saline soils. BioMed. Res. Int. 2014, article ID 589341: 1-2. http://dx.doi.org/10.1155/2014/589341

Herrero, J., Artieda, O. \& Hudnall, W.H. 2009. Gypsum, a tricky material. Soil Sci. Soc. Am. J. 73(6): 1757-1763.

Houba, V.J.G., Uittenbogaard, J. \& Pellen, P.J. 1994. International plant-analytical exchange (IPE). Chemical Composition of Various Plant Species. Wageningen Agric. Univ., Wageningen.

Huguet del Villar, E. 1925. Avance geobotánica sobre la pretendida estepa central de España. IV Lithoseries. Iberica 580: 344-350.

IUSS Working Group WRB. 2015. World Reference Base for Soil Resources 2014, update 2015 International soil classification system for naming soils and creating legends for soil maps. World Soil Resour. Rep. N. 106. FAO, Rome.

Johnston, I.M. 1941. Gypsophily among Mexican desert plants. J. Arnold Arbor. 22(2), 145-170.

Kartosentono, S., Nuraida, A., Indrayanto, G. \& Zaini, N.C. 2001. Phytoremediation of $\mathrm{Sr}^{2+}$ and its influence on the growth, $\mathrm{Ca}^{2+}$ and solasodine content of shoot cultures of Solanum laciniatum. J. Biotech. Lett. 23(2): 153-155.

Kasprzyk, A. 2013. Distribution of strontium in the Badenian (Middle Miocene) gypsum deposits of the Nida area, Southern Poland. Geol. Q. 38(3): 497-512.

Kirishima, A., Sasaki, T. \& Sato, N. 2015. Solution chemistry study of radioactive Sr on Fukushima Daiichi NPS site. J. Nucl. Sci. Technol. 52(2): 152-161.

Knight, H. 2000. Calcium signaling during abiotic stress in plants. Int. Rev. Cytol. 195: 269-324.

Linzon, S.N., Temple, P.J. \& Pearson, R.G. 1979. Sulfur Concentrations in Plant Foliage and Related Effects. J. Air Pollut. Control Assoc. 29(5): 520-525.

*Lowrey, T.K. \& Knight, P.J. 1994. Townsendia gypsophila (Compositae: Astereae): a new species from northern New Mexico. Brittonia 46(3): 194-199.

Maldonado, A.C., Olvera, H.F. \& Valdés, J. 2001. Las Euphorbiaceae halófilas y gipsófilas de México, excepto Euphorbia (parte a). An. Inst. Biol. Univ. Aut. México Bot. 72(1): 1-83.

Marchal F.M., Lendínez, M.L., Salazar, C. \& Torres, J.A. 2008. Contributions to the knowledge of gypsic vegetation in western Granada province (S. Spain). Lazaroa 29: 95-100.

*Martinez-Duro, E., Ferrandis, P., Escudero, A., Luzuriaga, A.L. \& Herranz, J.M. 2010. Secondary oldfield succession in an ecosystem with restrictive soils: Does time from abandonment matter? Appl. Veg. Sci. 13(2): 234-248.

Martínez-Hernández, F. 2013. Patrones biogeográficos de la flora gipsícola ibérica. PhD thesis. Univ. Almería, Almería.

Martínez-Hernández, F. Medina-Cazorla, J.M., Mendoza-Fernández, A., Pérez-García, F.J., SánchezGómez, P., Garrido-Becerra, J.A., Gil de Carrasco, C. \& Mota, J.F. 2009. Preliminary essay on the chorology of the Iberian gypsicolous flora: rarity and richness of the gypsum outcrops. Acta Bot. Gallica 156: 9-18.

*Martínez-Hernández, F., Mendoza-Fernández, A.J., Pérez-García, F.J., Martínez-Nieto, M.I., GarridoBecerra, J.A., Salmerón-Sánchez, E., Merlo, M.E., Gil, C. \& Mota, J.F. 2015. Areas of endemism as a conservation criterion for Iberian gypsophilous flora: a multi-scale test using the NDM/VNDM program. Plant Biosyst. 149(3): 483-493.

*Martínez-Hernández, F., Pérez-García, F.J., Garrido-Becerra, J.A., Mendoza-Fernández, A.J., MedinaCazorla, J.M., Martínez-Nieto, M.I., Merlo Calvente, M.E. \& Mota, J.F. 2011. The distribution of Iberian gypsophilous flora as a criterion for conservation policy. Biodiver. \& Conserv. 20(6): 13531364. DOI 10.1007/s10531-011-0031-2.

* Matesanz, S., Escudero, A. \& Valladares, F. 2009. Impact of three global change drivers on a Mediterranean shrub. Ecology 90(9): 2609-2621.

Megías, A.G., Sánchez-Piñero, F. \& Hódar, J.A. 2011. Trophic interactions in an arid ecosystem: From decomposers to top-predators. J. Arid Environ. 75: 1333-1341.

Mendoza-Fernández, A.J., Spampinato, G., Musarella, C.M., Martínez-Hernández, F., Salmerón-Sánchez, E., Merlo, E. \& Mota J.F. 2016. Leaf analyses of gypsophile flora from Sicily. In: Bacchetta, G. (Ed.). Conservation studies on Mediterranean threatened flora and vegetation. Book of Abstracts of the X International Meeting Biodiversity Conservation and Management, Sardinia 13-18 June. Pp. 52.Univ. Cagliari, Italy. 
Mengoni, A., Schat, H. \& Vangronsveld, J. 2010. Plants as extreme environments? Ni-resistant bacteria and Ni-hyperaccumulators of serpentine flora. Plant Soil 331(1-2): 5-16.

Menzel, U. \& Lieth, H. 2003. HALOPHYTE Database Vers. 2.0 update. In: Lieth, H. \& Mochtchenko, M. (Eds.). Cash Crop Halophytes. Pp. 221-223 (and compact disc). Kluwer, Dordrecht.

Merlo, M.E., Mota, J.F., Alemán, M.M. \& Cabello, J. 1998. La gipsofilia en plantas: un apasionante edafismo. Investigación y Gestión 3:103-112.

*Merlo, M.E., Gil de Carrasco, C., Sola Gómez, A.J., Jiménez Sánchez, M.L., Rodríguez Tamayo, M.L. \& Mota, J.F. 2009. Can gypsophytes distinguish different types of gypsum habitats? Acta Bot. Gallica 156(1):63-78.

Merlo, M.E., Mota, J.F. \& Sánchez Gómez, P. 2011. Ecofisiología y adaptaciones de las plantas vasculares a las características físicas y químicas de sustratos especiales. In: Mota, J.F., Sánchez-Gómez, P. \& Guirado Romero, J.S. (Eds.). Diversidad vegetal de las yeseras ibéricas. Pp. 51-74. ADIF-Mediterráneo Asesores Consultores. Almería.

Merlo, M.E., Rodríguez-Tamayo, M.L., Jiménez, M.L., \& Mota, J.F. 2001. Recapitulación sobre el comportamiento biogeoquímico de algunos gipsófitos y halófitos ibéricos. Monogr. Fl. Veg. Béticas 12: 7795.

*Meyer, S.E. 1986. The ecology of gypsophile endemism in the eastern Mojave Desert. Ecology 67: 13031313.

*Meyer, S.E., García-Moya, E. \& Lagunes-Espinoza, L.D.C. 1992. Topographic and soil surface effects on gypsophile plant community patterns in central Mexico. J. Veg. Sci. 3(3): 429-438.

Molano-Flores, B. 2001. Herbivory and calcium concentrations affect calcium oxalate crystal formation in leaves of Sida (Malvaceae). Ann. Bot. (Oxford) 88: 387-391.

*Moore M.J., Mota J.F., Douglas N.A., Flores Olvera H. \& Ochoterena, O. 2014. The ecology, assembly and evolution of gypsophile floras. In: Rajakaruna, N., Boyd, R.S. \& Harris, T.B. (Eds.) Plant ecology and evolution in harsh environments. Pp. 97-128. Sci. Publ., Hauppauge, NY, USA.

*Moore, M.J. \& Jansen, R.K. 2007. Origins and biogeography of gypsophily in the Chihuahuan Desert plant group Tiquilia subg. Eddya (Boraginaceae). System. Bot. 32(2): 392-414.

Mota, J.F., Garrido-Becerra, J.A., Merlo, M.E., Medina-Cazorla, J.M. \& Sánchez-Gómez, P. 2017. The edaphism: gypsum, dolomite and serpentine flora and vegetation. In: Loidi, J. \& Werger, M.J.A. (Eds.). The Vegetation of the Iberian Peninsula. Springer (in press).

*Mota, J.F., Garrido-Becerra, J.A., Pérez-García, F.J., Sola, A.J. \& Valle, F. 2010. Use of the MultiResponse Permutation Procedure and Indicator Species Value for the statistical classification of the gypsicolous Iberian scrub communities. Candollea 65(1): 117-134.

Mota, J.F., Merlo, M.E., \& Izco, J. 2011. Recorrido histórico por la investigación botánica sobre la flora y vegetación gipsófilas en España. In: Mota, J.F., Sánchez-Gómez, P. \& Guirado Romero J.S. (Eds.). Diversidad vegetal de las yeseras ibéricas. Pp. 75-88. ADIF-Mediterráneo Asesores Consultores. Almería.

Mota, J.F., Sánchez-Gómez, P. \& Guirado Romero, J.S. (Eds.). 2011. Diversidad vegetal de las yeseras ibéricas. ADIF-Mediterráneo Asesores Consultores. Almería.

Mota, J.F., Sánchez-Gómez, P., Merlo, M.E., Catalán, P., Laguna, E., de la Cruz, M., Navarro-Reyes, F.B., Marchal, F., Bartolomé, C., Martínez Labarga, J.M., Sainz Ollero, H., Valle, F., Serra, L., MartínezHernández, F., Garrido-Becerra, J.A. \& Pérez-García, F.J. 2009. Aproximación a la checklist de los gipsófitos ibéricos. An. Biol. 31: 71-80.

*Mota, J.F., Sola A.J., Dana E.D. \& Jiménez-Sánchez M.L. 2003. Plant succession in abandoned gypsum quarries in Southeast Spain. Phytocoenologia 33: 13-2.

*Mota, J.F., Sola-Gómez, A.J., Jiménez-Sánchez, M.L., Pérez-García, F.J. \& Merlo, M.E. 2004. Gypsicolous flora, conservation and restoration of quarries in the southeast of the Iberian Peninsula. Biodivers. \& Conserv. 13: 1797-1808.

Musarella, C.M., Spampinato, G., Mendoza-Fernández, A.J., Mota, J.F., Alessandrini, A., Brullo S., Caldarella, O., Ciaschetti, G., Conti, F., Di Martino, L., Falci, A., Gianguzzi, L., Guarino, R., Manzi, A., Minissale, P., Montanari, S., Pasta, S., Peruzzi, L., Sciandrello, S., Scuderi, L. \& Troì A. 2016. Preliminary checklist of the Italian gypsophilous flora. In: Bacchetta, G. (Ed.). Conservation studies on Mediterranean threatened flora and vegetation. Book of Abstracts of the X International Meeting Biodiversity Conservation and Management, Sardinia 13-18 June. Pp. 53. Univ. Cagliari, Italy.

Nakata, P.A. 2003. Advances in our understanding of calcium oxalate crystal formation and function in plants. Plant Sci. 164(6): 901-909.

*Nesom, G.L.A. 2007. A New gypsophilous species of Erigeron (Asteraceae: Astereae) from Northeastern Mexico. J. Bot. Res. Inst. Tex. 1(2): 891-894.

*Northington, D.K. 1976. Evidence bearing on the origin of infraspecific disjunction in Sophora gypsophila (Fabaceae). Plant Sys. Evol. 125(4): 233-244. 
*Oyonarte, C., Sanchez, G., Urrestarazu, M. \& Alvarado, J.J. 2002. A comparison of chemical properties between gypsophile and nongypsophile plant rhizospheres. Arid Land Res. Manag. 16: 47-54.

Özdemir, C., Özkan, M. \& Kandemir, A. 2010. The morphological and anatomical properties of Gypsophila lepidioides Boiss. (Caryophyllaceae) endemic to Turkey. Int. Res. J. Plant Sci. 1:69-74.

*Palacio, S., Escudero, A., Montserrat-Martí, G., Maestro, M., Milla, R. \& Albert, M.J. 2007. Plants living on gypsum: Beyond the specialist model. Ann. Bot. (Oxford): 99: 333-343.

*Palacio, S., Aitkenhead, M., Escudero, A., Montserrat-Martí, G., Maestro, M. \& Robertson, J. 2014a. Gypsophile Chemistry Unveiled: Fourier Transform Infrared (FTIR) Spectroscopy Provides New Insight into Plant Adaptations to Gypsum Soils. PLoS ONE 9(9): e107285. doi:10.1371/journal.pone.0107285

*Palacio, S., Azorín, J., Montserrat-Martí, G. \& Ferrio, J.P. 2014b. The crystallization water of gypsum rocks is a relevant water source for plants. Nature Comm. 5: 4660. doi: 10.1038/ncomms5660

*Palacio, S., Johnson, D., Escudero, A. \& Montserrat-Martí, G. 2012. Root colonisation by AM fungi differs between gypsum specialist and non-specialist plants: Links to the gypsophile behavior. J. Arid Environ. 76(1): 128-132.

Parsons, R.F. 1976. Gypsophily in plants-a review. Am. Midl. Nat. 96: 1-20.

Pérez-García F.J., Martínez-Hernández, F., Mendoza, A.J., Merlo, M.E., Salmerón-Sánchez, E., GarridoBecerra, J.A. \& Mota J.F. 2016. Towards a global checklist of the gypsophytes of the World. In: Bacchetta, G. (Ed.). Conservation studies on Mediterranean threatened flora and vegetation. Book of Abstracts of the X International Meeting Biodiversity Conservation and Management, Sardinia 13-18 June. Pp. 41. University of Cagliari, Italy.

Pérez-García, F.J., Martínez-Hernández. F., Garrido-Becerra, J.A., Mendoza-Fernández, A.J., MedinaCazorla, J.M., Martínez-Nieto, M.I. \& Mota, J.F. 2011. Biogeografía de la conservación en los aljezares ibéricos: Patrones corológicos y selección de reservas. In: Mota J.F., Sánchez-Gómez, P. \& Guirado Romero J.S. (Eds.). Diversidad vegetal de las yeseras ibéricas. Pp. 569-586. ADIF-Mediterráneo Asesores Consultores. Almería.

Poch, R.M., De Coster, W. \& Stoops, G. 1998. Pore space characteristics as indicator of soil behaviour in gypsiferous soils. Geoderma 87: 87-109.

Popper, K.R. 1959. The logic of scientific discovery. Hutchinson, London.

*Porras-Alfaro, A., Raghavan, S., Garcia, M., Sinsabaugh, R.L., Natvig, D.O. \& Lowrey, T.K. 2014. Endophytic fungal symbionts associated with gypsophilous plants. Botany 92(4): 295-301.

*Pueyo, Y., Alados, C.L., Barrantes, O., Komac, B. \& Rietkerk, M. 2008. Differences in gypsum plant communities associated with habitat fragmentation and livestock grazing. Ecol. Appl. 18(4): 954-964.

*Pueyo, Y., Alados, C.L., Maestro, M. \& Komac, B. 2007. Gypsophile vegetation patterns under a range of soil properties induced by topographical position. Plant Ecol. 189(2): 301-311.

*Queiroz, T.F.D., Baughman, C., Baughman, O., Gara, M. \& Williams, N. 2012. Species distribution modeling for conservation of rare, edaphic endemic plants in White River Valley, Nevada. Nat. Area. J. 32(2): 149-158.

Reid, N. \& Hill, S.M. 2010. Biogeochemical sampling for mineral exploration in arid terrains: Tanami Gold Province, Australia. J. Geochem. Explora 104(3): 105-117.

Reid, N. \& Hill, S.M. 2013. Spinifex biogeochemistry across arid Australia: Mineral exploration potential and chromium accumulation. Appl. Geochem. 29: 92-101.

Reid, N., Hill, S.M. \& Lewis, D.M. 2008. Spinifex biogeochemical expressions of buried gold mineralisation: the great mineral exploration penetrator of transported regolith. Appl. Geochem. 23(1):76-84.

Reyes Prósper, E. 1915. Las estepas de España y su vegetación. Esc. Tip. "Sucesores de Rivadeneyra". Madrid.

Rick, A.C. 2012. Survey and analysis of plant communities growing on gypsum in the Western Australian Wheatbelt. Report for the Wheatbelt NRM region and the department of environment and conservation. Newdegate, WA, Australia.

*Rincón, A., Arenal, F., González, I., Manrique, E., Lucas, M.M. \& Pueyo, J.J. 2008 Diversity of rhizobial bacteria isolated from nodules of the gypsophyte Ononis tridentata L. growing in Spanish soils. Microb. Ecol. 56(2): 223-233.

Roberts, B.A. \& Proctor, J. (Eds.). 1992 (ed. 2013). The ecology of areas with serpentinized rocks: a world view. Springer Sci. \& Business Media.

*Robins, C.R., Buck, B.J. \& Williams, A.J. 2014. Establishing soil and surficial geologic habitat criteria for presumed gypsophiles. The example of Eriogonum corymbosum var. nilesii, Mojave Desert, U.S.A. Catena 118: 9-19.

*Romão, R.L. \& Escudero, A. 2005. Gypsum physical soil crusts and the existence of gypsophytes in semiarid central Spain. Plant Ecol. 181(1): 127-137. 
Rosell, L., Orti, F., Kasprzyk, A., Playa, E. \& Peryt, T.M. 1998. Strontium geochemistry of Miocene primary gypsum: Messinian of southeastern Spain and Sicily and Badenian of Poland. J. Sediment. Res. 68(1): 63-79.

*Salazar, G.A., Chávez-Rendón, C., De Ávila B., \& Jiménez-Machorro, R. 2016. Floral similarity and vegetative divergence in a new species of Bletia (Orchidaceae) from Mexico. Phytotaxa 275(2): 112-126.

*Salmerón-Sánchez, E., Martínez-Nieto, M.I., Martínez-Hernández, F., Garrido-Becerra, J.A., MendozaFernández, A.J., Gil de Carrasco, C., Ramos-Miras, J.J., Lozano, R., Merlo M.E. \& Mota, J.F. 2014a. Ecology, genetic diversity and phylogeography of the Iberian endemic plant Jurinea pinnata (Lag.) DC. (Compositae) on two special edaphic substrates: Dolomite and gypsum. Plant Soil: 374 (1-2): 233-250.

Sánchez del Pino, I., Flores Olvera, H. \& Valdés, J. 1999. La familia Amaranthaceae en la flora halófila y gipsófila de México. An. Inst. Biol. Univ. Aut. México Bot. 70(1): 29-135.

Santos, J., Al-Azzawi, M., Aronson, J. \& Flowers, T.J. 2016. e-HALOPH a database of salt-tolerant plants: helping put halophytes to work. Plant Cell Physiol. 57(1): e10 (1-10)

Saslis-Lagoudakis, C.H., Moray, C. \& Bromham, L. 2014. Evolution of salt tolerance in angiosperms: a phylogenetic approach. In: Rajakaruna, N., Boyd, R.S. \& Harris, T.B. (Eds.) Plant Ecology and evolution in harsh environments. Pp. 77-95. Nova Science Publishers, Hauppauge, NY, USA.

Sheoran, V., Sheoran, A. \& Poonia, P. 2011. Role of hyperaccumulators in phytoextraction of metals from contaminated mining sites: a review. Crit. Rev. Environ. Sci. Technol. 41: 168-214.

Silva-Graça, M., Neves, L. \& Lucas, C. 2003. Outlines for the definition of halotolerance/halophily in yeasts: Candida versatilis (halophila) CBS4019 as the archetype?. FEMS Yeast Res. 3(4): 347-362.

Singh, S., Eapen, S., Thorat, V., Kaushik, C.P., Raj, K. \& D’Souza, S.F. 2008. Phytoremediation of 137 cesium and 90 strontium from solutions and low-level nuclear waste by Vetiveria zizanoides. Ecotoxicol. Environ. Saf. 69(2): 306-311.

*Soriano, P., Moruno, F., Boscaiu, M., Vicente, O., Hurtado, A., Llinares, J.V. \& Estrelles, E. 2014. Is salinity the main ecologic factor that shapes the distribution of two endemic Mediterranean plant species of the genus Gypsophila? Plant Soil 384 (1-2): 363-379.

Spaargaren, O. 2008. Gypsisols. In: Chesworth, W. (Ed.). Encyclopedia of Soil Science. Pp. 301-302. Springer, New York.

Szota, C., Farrell, C., Livesley, S.J., \& Fletcher, T.D. 2015. Salt tolerant plants increase nitrogen removal from biofiltration systems affected by saline stormwater. Water Res. 83:195-204.

Torrecillas, E., Alguacil, M.M., Roldán, A., Díaz, G., Montesinos-Navarro, A., Torres, M.P. 2014. Modularity reveals the tendency of arbuscular mycorrhizal fungi to interact differently with generalist and specialist plant species in gypsum soils. Appl. Environ. Microbiol. 80(17): 5457-5466.

Tuyukina, T.Y. 2009. Geochemical studies of northern taiga (gypsum) karst ecosystems and their high vulnerability to natural and anthropogenic hazards. Environ. Geol. 58(2): 269-274.

Van Alphen, J.G. \& Rios Romero, F. 1971. Gypsiferous soils, notes on their characteristics and management. International Institute for Land Reclamation and Improvement. Wageningen.

Van Der Gaag, P. 2008. Mining water from gypsum. Int. J. Global Environ. Issues 8(3): 274-281.

Verheye, W.H. \& Boyadgiev, T.G. 1997. Evaluating the land use potential of gypsiferous soils from field pedogenic characteristics. Soil Use Manage. 13(2): 97-103.

Waisel, Y. 1972. Biology of Halophytes. Academic Press. New York and London.

Watanabe, T., Broadley, M.R., Jansen, S., White, P.J., Takada, J., Satake, K., Takamatsu, T., Tuah, S.J. \& Osaki, M. 2007. Evolutionary control of leaf element composition in plants. New Phytol. 174(3): 516523.

Waterfall, U.T. 1946. Observations on the desert gypsum flora of southwestern Texas and adjacent New Mexico. Am. Midl. Nat. 36(2): 456-466.

Weinert, E. \& Sakri F.A. 1977. Sulfate content in plant tissues of some Iraqi desert plants. Flora. 166: 65-73.

Yang, S., Zhong, Y., Luo, H., Ding, X. \& Zuo C.1999. Studies on chemical constituents of the roots of Gypsophila oldhamiana Miq. Zhongguo Zhong Yao Za Zhi. 24(11): 680-1, 703.

*Yildirim, H. \& Crespo, M.B. 2014. Acantholimon riyatguelii (Plumbaginaceae), a threatened new unarmed species from Central Anatolia, Turkey. Phytotaxa 175(2): 73-84.

\section{Appendix}

We present a list of other bibliography related to gypsophytes that has been consulted to write the present paper but not referenced in the text.

*Alonso-Redondo, R., De Paz, E., Alonso-Herrero, E., García-González, M.-E. \& Alfaro-Saiz, E. 2013. A new method for calculating Risk Tolerance in the assessment of threatened flora. J. Nat. Conserv. 21(6): 414-422. 
*Alvarado, J.J., Ruiz, J.M., López-Cantarero, I., Molero, J. \& Romero, L. 2000. Nitrogen metabolism in five plant species characteristic of gypsiferous soils. J. Plant Physiol. 156 (5/6): 612-616.

*Aragón, C.F., Albert, M.J., Giménez-Benavides, L., Luzuriaga, A.L. \& Escudero, A. 2007. Environmental scales on the reproduction of a gypsophyte: A hierarchical approach. Ann. Bot. (Oxford): 99(3): 519-527.

*Aragón, C.F. \& Escudero, A. 2009. Mating system of Helianthemum squamatum (Cistaceae), a gypsophile specialist of semi-arid Mediterranean environments. Bot. Helv. 118(2): 129-137.

*Ballesteros, M. Cañadas, E.M., Foronda, A., Fernández-Ordoño, E., Peñas, J. \& Lorite, J. 2012. Vegetation recovery of gypsum quarries: short-term sowing response to different soil treatments. Appl. Veg. Sci. 15(2): 187-197.

*Ballesteros, M., Cañadas, E.M., Foronda, A., Peñas, J., Valle F. \& Lorite, J. 2014. Central role of bedding materials for gypsum-quarry restoration: An experimental planting of gypsophile species. Ecol. Eng. 70: 470-476.

*Ballesteros, M., Foronda, A., Cañadas, E.M., Peñas \& Lorite, J. 2013. Conservation status of the narrow endemic gypsophile Ononis tridentata subsp. crassifolia in southern Spain: Effects of habitat disturbance. Oryx 47(2): 199-202.

*Banda-Leal, J., Lazcano, D., de los Reyes, M.N. \& Barriga-Vallejo, C. 2014. Gerrhonotus parvus Knight \&amp; Scudday, 1985 (Squamata: Anguidae): New range extension and clutch size in the state of Nuevo León, Mexico. Check List 10(4): 950-953.

*Boukhris, A. Laffont-Schwob, I. Rabier, J. Salducci, M.D. El Kadri, L., Tonetto, A., Tatoni, T. \& Chaieb, M. 2015. Changes in mesophyll element distribution and phytometabolite contents involved in fluoride tolerance of the arid gypsum-tolerant plant species Atractylis serratuloides Sieber ex Cass. (Asteraceae). Environ. Sci. Pollut. Res. 22(10): 7918-7929.

*Casares-Porcel, M. \& Gutierrez-Carretero, L. 1993. Sintesis de la vegetacion liquenica gipsicola termoy mesomediterranea de la Peninsula Iberica. Cryptogam. Bryol. Lichen. 14(4): 361-388.

*Dana, E. \& Mota, J.F. 2006. Vegetation and soil recovery on gypsum outcrops in semi-arid Spain. J. Arid Environ. 65: 444-459.

*De La Cruz, M., Romão, R.L., Escudero, A. \& Maestre, F.T. 2008. Where do seedlings go? A spatio-temporal analysis of seedling mortality in a semi-arid gypsophyte. Ecography 31(6): 720-730.

*Escudero, A., Martínez, I., de la Cruz, A., Otálora, M.A.G. \& Maestre, F.T. 2007. Soil lichens have species-specific effects on the seedling emergence of three gypsophile plant species. J. Arid Environ. 70(1): 18-28.

*Eugenio, M., Olano, J.M., Ferrandis, P., Martínez-Duro, E. \& Escudero, A. 2012. Population structure of two dominant gypsophyte shrubs through a secondary plant succession. J. Arid Environ. 76(1): 30-35.

*García-Fernández, A., de Haro Reyes, B. \& Escudero, A. 2014. Identification and development of eight microsatellite markers for the gypsophyte Helianthemum squamatum and cross-species amplification. Conserv. Genet. Resour. 6(4): 1049-1051.

*Gómez-Fernández, A., Alcocer, I. \& Matesanz, S. 2016. Does higher connectivity lead to higher genetic diversity? Effects of habitat fragmentation on genetic variation and population structure in a gypsophile. Conserv. Genet. 17(3): 631-641.

*Granzow-de la Cerda, I., Arellano, G., Brugués, M. \& Solà-López, A. 2016. The role of distance and habitat specificity in bryophyte and perennial seed plant metacommunities in arid scrubland fragments. J. Veg. Sci. 27(2): 414-426.

*Guerra, J., Martinez-Sanchez, J.J. \& Ros, R.M. 1992. On the degree of adaptation of the moss flora and vegetation in gypsiferous zones of the south-east Iberian Peninsula. J. Bryol. 17(1): 133-142.

*Harper, K.T. \& Van Buren, R. 2004. Dynamics of a dwarf bear-poppy (Arctomecon humilis) population over a sixteen-year period. West. N. Am. Natur. 64(4): 482-491.

*Hicks, A.L. \& Whitcomb, R.F. 1996. Diversity of the leafhopper (Homoptera: Cicadellidae) fauna of northern Chihuahuan grasslands, with emphasis on gypsum grasslands and description of a new species of Athysanella (Cicadellidae: Deltocephalinae). Proc. Entomol. Soc. Wash. 98(1): 145-157.

*Luévano, J., Mellink, E., Riojas-López, M.E. \& Flores-Flores, J.L. 2008. Comunidades de roedores nocturnos en un ecotono de matorrales micrófilos y zacatal gipsófilo en San Luis Potosí, México. Rev. Mex. Biodivers. 79(1): 197-203.

*Martínez-Duro, E., Ferrandis, P. \& Herranz, J.M. 2009. Factors controlling the regenerative cycle of Thymus funkii subsp. funkii in a semi-arid gypsum steppe: A seed bank dynamics perspective. J. Arid Environ. 73(3): 252-259.

*Martinez-Duro, E., Luzuriaga, A.L., Ferrandis, P., Escudero, A. \& Herranz, J.M. 2012. Does aboveground vegetation composition resemble soil seed bank during succession in specialized vegetation on gypsum soil? Ecol. Res. 27(1): 43-51.

*Martínez-Nieto, M.I., Merlo, M.E., Mota, J.F., Salmerón-Sánchez, E. \& Segarra-Moragues, J.G. 2012. Microsatellite loci in the gypsophyte Lepidium subulatum (Brassicaceae), and transferability to other Lepidieae. Int. J. Mol. Sci. 13(9): 11861-11869. 
*Martínez-Nieto, M.I., Segarra-Moragues, J.G., Merlo, E., Martínez-Hernández, F. \& Mota, J.F. 2013. Genetic diversity, genetic structure and phylogeography of the Iberian endemic Gypsophila struthium (Caryophyllaceae) as revealed by AFLP and plastid DNA sequences: Connecting habitat fragmentation and diversification. Bot. J. Linn. Soc. 173(4): 654-675.

*Medina-Cazorla, J.M., De Carrasco, C.G., Merlo, M.E., Martínez-Hernández, F., Garrido-Becerra, J.A., Salmerón, E., Mendoza, A.J., Pérez-García, F.J. \& Mota, J.F. 2010. The dolomite shrublands of the Convolvuletalia boissieri order and their preservation by means of the Habitats Directive. Acta Bot. Gallica, 157(4): 611-625.

*Navarro-Cano, J.A., Ferrer-Gallego, P.P., Laguna, E., Ferrando, I., Goberna, M., Valiente-Banuet, A. \& Verdú, M. 2016. Restor. Ecol. 24(4): 449-455.

*Navarro-Cano, J.A., Goberna, M., Valiente-Banuet, A., Montesinos-Navarro, A., García, C. \& Verdú, M. 2014. Plant phylodiversity enhances soil microbial productivity in facilitation-driven communities. Oecologia 174(3): 909-920.

*Pías, B., Matesanz, S., Herrero, A., Gimeno, T.E., Escudero, A. \& Valladares, F. 2010. Transgenerational effects of three global change drivers on an endemic Mediterranean plant. Oikos 119(9):1435-1444.

*Pueyo, Y. \& Alados, C.L. 2007. Abiotic factors determining vegetation patterns in a semi-arid Mediterranean landscape: Different responses on gypsum and non-gypsum substrates. J. Arid Environ. 69(3): 490-505.

*Rzedowski, J. 1986. Las plantas calcicolas (incluyendo una gipsofita) del Valle de México y sus ligas con la erosión edáfica. Biotropica 18(1): 12-15.

*Saiz, H., Alados, C.L. \& Pueyo, Y. 2014. Plant-plant spatial association networks in gypsophilous communities: The influence of aridity and grazing and the role of gypsophytes in its structure. Ecology 14(1): 39-49.

*Salmerón-Sánchez, E., Pérez-García, F.J., Medina-Cazorla, J.M., Martínez-Nieto, M.I., MartínezHernández, F., Garrido-Becerra, J.A., Mendoza-Fernández, A.J., Calvente, M.E. \& Poveda, J.F. 2015. Genetic analysis based on plastidial and ribosomal sequences of the endemic bi-edaphic taxon Jurinea pinnata (Lag.) DC. (Compositae) in the Guadix-Baza Basin. Plant Biosyst. 149(5): 922-932.

*Tepedino, V.J., Mull, J., Griswold, T.L. \& Bryant, G. 2014. Reproduction and pollination of the endangered dwarf bear-poppy Arctomecon humilis (Papaveraceae) across a quarter century: Unraveling of a pollination web? West. N. Am. Nat. 74(3): 311-324.

*Tkachenko, K.G. 1985. Ephedra cenoecotypes on the Aral coastline. Problemy Osvoeniya Pustyn. Akademiya Nauk Turkmenskoi SSR 2: 66-69.

*Walter, H. \& Box, E.O. 1983. Middle Asian deserts. In: West, N.E. (Ed.). Temperate deserts and semideserts. Ecosystem of the World, vol. 5. Pp. 9-41. Elsevier, New York.

*Williams, E.W., Cheung, R., Siegel, C., Howard, M., Fant, J. \& Havens, K. 2016. Persistence of the gypsophile Lepidospartum burgessii (Asteraceae) through clonal growth and limited gene flow. Conserv. Genet. 17(5): 1201-1211. 